\title{
Forecasting the labour markets for research scientists and engineers in the European Union
}

Citation for published version (APA):

Marey, P. S., de Grip, A., \& Cörvers, F. (2001). Forecasting the labour markets for research scientists and engineers in the European Union. Researchcentrum voor Onderwijs en Arbeidsmarkt, Faculteit der Economische Wetenschappen. ROA Working Papers No. 3E https://doi.org/10.26481/umarow.200103E

Document status and date:

Published: 01/01/2001

DOI:

10.26481/umarow.200103E

Document Version:

Publisher's PDF, also known as Version of record

\section{Please check the document version of this publication:}

- A submitted manuscript is the version of the article upon submission and before peer-review. There can be important differences between the submitted version and the official published version of record.

People interested in the research are advised to contact the author for the final version of the publication, or visit the DOI to the publisher's website.

- The final author version and the galley proof are versions of the publication after peer review.

- The final published version features the final layout of the paper including the volume, issue and page numbers.

Link to publication

\footnotetext{
General rights rights.

- You may freely distribute the URL identifying the publication in the public portal. please follow below link for the End User Agreement:

www.umlib.nl/taverne-license

Take down policy

If you believe that this document breaches copyright please contact us at:

repository@maastrichtuniversity.nl

providing details and we will investigate your claim.
}

Copyright and moral rights for the publications made accessible in the public portal are retained by the authors and/or other copyright owners and it is a condition of accessing publications that users recognise and abide by the legal requirements associated with these

- Users may download and print one copy of any publication from the public portal for the purpose of private study or research.

- You may not further distribute the material or use it for any profit-making activity or commercial gain

If the publication is distributed under the terms of Article $25 \mathrm{fa}$ of the Dutch Copyright Act, indicated by the "Taverne" license above, 


\title{
Forecasting the Labour Markets for Research Scientists and Engineers in the European Union
}

\author{
ROA-W-2001/3E
}

Philip Marey, Andries de Grip and Frank Cörvers

Research Centre For Education and the Labour Market

Faculty of Economics and Business Administration

Maastricht University

Maastricht, March 2001 
ISBN 90-5321-307-4

Sec01.039.doc 


\section{Contents}

Acknowledgements

Abstract

1 Introduction

2 The model

3 Scenario analysis

4 Quantification of scenarios

5 Implementation of scenarios

6 Forecasts

7 Conclusion

References 



\section{Acknowledgements}

This working paper has been published as Annex 2 of Assessing the Supply and Demand for Scientists and Technologists in Europe by R. Pearson, N. Jagger, H. Connor, S. Perryman, P. Marey, A. de Grip, F. Cörvers, IES Report 377, Brighton, U.K., 2001. This report is based on a study carried out by the Institute for Employment Studies (IES) and the Research Centre for Education and the Labour Market (ROA) supported by the Research Directorate of the European Commission. We are grateful for the assistance given by Ugur Muldur, Jacques Zachmann, Ian Perry, Jean Bourlès and their colleagues in the European Commission. 


\begin{abstract}
The aim of this study is to assess whether the higher education systems in the Member States of the European Union will produce sufficient numbers of science \& technology (S\&T) graduates to meet the demands for research scientists and engineers (RSE's) up to 2002. On the demand side, we distinguish between job openings due to employment growth (expansion demand) and due to outflow (replacement demand). Employment of RSE's is modelled as an error correction mechanism with $R \& D$ expenditure as the explanatory variable. A recent survey of European $R \& D$ establishments enables us to determine replacement demand. On the supply side, the labour market inflow of RSE's is derived from data on S\&T-graduates and RSE employment. We produce forecasts for demand and supply for 14 Member States of the EU under four alternative scenarios, which are based on two dimensions: economic growth and human capital policy. The forecasts are first used to identify labour market discrepancies by country and by field of study. Then we identify the opportunities for international labour mobility to solve the bottlenecks in the labour markets. The forecasting results indicate considerable shortages of RSE's in certain fields of study in various Member States of the EU under certain scenarios. At the same time, for the EU as a whole there are excess supplies in each of the four fields of study distinguished, no matter which scenario will unfold up to 2002, illustrating the importance of international labour mobility.
\end{abstract}




\section{Introduction}

In the 'White Paper' on growth, competitiveness and employment, the European Commission states that the European Union (EU) should catch up in the technological race if it wishes to increase employment levels (Commission of the European Communities, 1993). Rapid technological change offers great opportunities for increasing employment in the EU, and the diffusion of new technologies is crucial for the EU's international competitive position. However, this requires a highly skilled labour force that gives competitive advantages in the growth sectors of the world economy.

Economic growth and rising employment usually correspond with productivity increases, mainly caused by technological progress (OECD, 1994). Productivity gains in the economy as a whole depend to a large extent on developments in the high-technology segment of the manufacturing sector and the employment in many other sectors of the economy will suffer in a situation where there is scarcity of skilled labour (Reich, 1991).

Knowledge-intensive sectors, both in manufacturing and in services, have been expanding their employment more rapidly than the rest of the economy. The importance of hightechnology products has increased continuously in international trade. In particular, industries related to information technologies are the fastest growing categories in world trade and production. Information technologies increase the potential for economic growth and productivity gains, but due to their characteristics also broaden the mismatches between labour demand and supply in terms of skills and qualifications. Efficient implementation requires considerable changes in work organisation and skills requirements (OECD, 1994).

In a knowledge-driven global economy, it is essential that the education systems in the Member States of the EU produce sufficient science \& technology (S\&T) graduates both in quantitative and qualitative terms. The hard core of personnel in the R\&D departments are the research scientists and engineers (RSE's). Any shortage in qualified RSE's will lead to unrealised output of knowledge and consequently a loss in product quality and variety. This in turn will hurt the international competitiveness of European firms and will result in lower market shares in technology-intensive products and services. The opportunities for economic growth and economy-wide employment will not be fully exploited. The loss in market share decreases the employment possibilities for other workers in the sectors that could be the growth sectors of the economy, such as technicians and supporting staff. Moreover, there will probably be large negative spillover effects to other sectors of the economy.

From a policy perspective, the availability of reliable forecasts on the adequacy of the education systems in the Member States of the EU to meet the future demand for RSE's, is therefore very important. Such forecasts could be an essential tool for policy-makers, as they serve as an 'early warning system' indicating possible bottlenecks in the labour markets for RSE's. It will give policy-makers the opportunity to initiate anticipating policies. This pilot study explores the possibilities of developing a forecasting system for the European labour markets for RSE's and tries to establish what type of analyses are possible with the currently 
available data on R\&D personnel and to identify the obstacles that stand in the way of a more reliable forecasting system. For this purpose, the pilot study produces forecasts for future demand and supply of RSE's for 14 Member States of the EU in the period 19972002, based on available data up to 1997. It offers an exploratory assessment of the expected quantitative adequacy of the education systems in the Member States of the EU in the period 1997-2002 in relation to the demand for RSE's, based on information up to 1997. It is important to emphasise that these forecasts are not yet suitable for policy purposes. The main purpose is to show the potential features of an early warning system for bottlenecks in the labour markets for RSE's which play a crucial role in the European knowledge economy. The remainder of this working paper is organised as follows. Section 2 describes the general structure of the labour market forecasting model. Section 3 discusses the scenarios which are based on two dimensions: the exogenous dimension (real GDP growth) and the policy dimension (expenditure on R\&D and higher education). The four scenarios are quantified in section 4. Section 5 describes the implementation of the scenarios in terms of the forecasting model. The forecasts for demand and supply under the four scenarios are discussed in section 6 and compiled in the appendix. Section 7 concludes.

\section{The model}

In order to assess the quantitative adequacy of the education systems in 14 Member States of the EU in the period 1997-2002 in relation to the demand for RSE's, we developed a model to track the relevant flows on the labour markets for RSE's. Under this approach forecasts are made of the flows entering and leaving the labour market in the period 19972002. This approach enables us to make a confrontation between labour demand (the expected job openings for RSE's) and labour supply (the expected inflow of new RSE's). The general structure of the labour market forecasting model for each of the 14 Member States is visualised in Figure 1.

The demand for RSE's consists of two components. In the first place, job openings may occur due to growth of R\&D employment. This is called expansion demand. In the second place, there are job openings because of the outflow of workers due to retirement and the mobility of RSE's to commercial and management jobs. This is called replacement demand. Expansion demand and replacement demand are considered in three sectors of R\&D work: the business enterprise sector, the government sector and the higher education sector. The forecasting results for the demand side are summarised in terms of the total number of job openings between 1997 and 2002.

From the supply side, the job openings for RSE's will in general be filled by the flow of new $S \& T$ graduates from the educational systems of the Member States of the EU. The flow of S\&T graduates is also largely determined by demographic developments. 
Figure 1

General structure of the labour market forecasting model

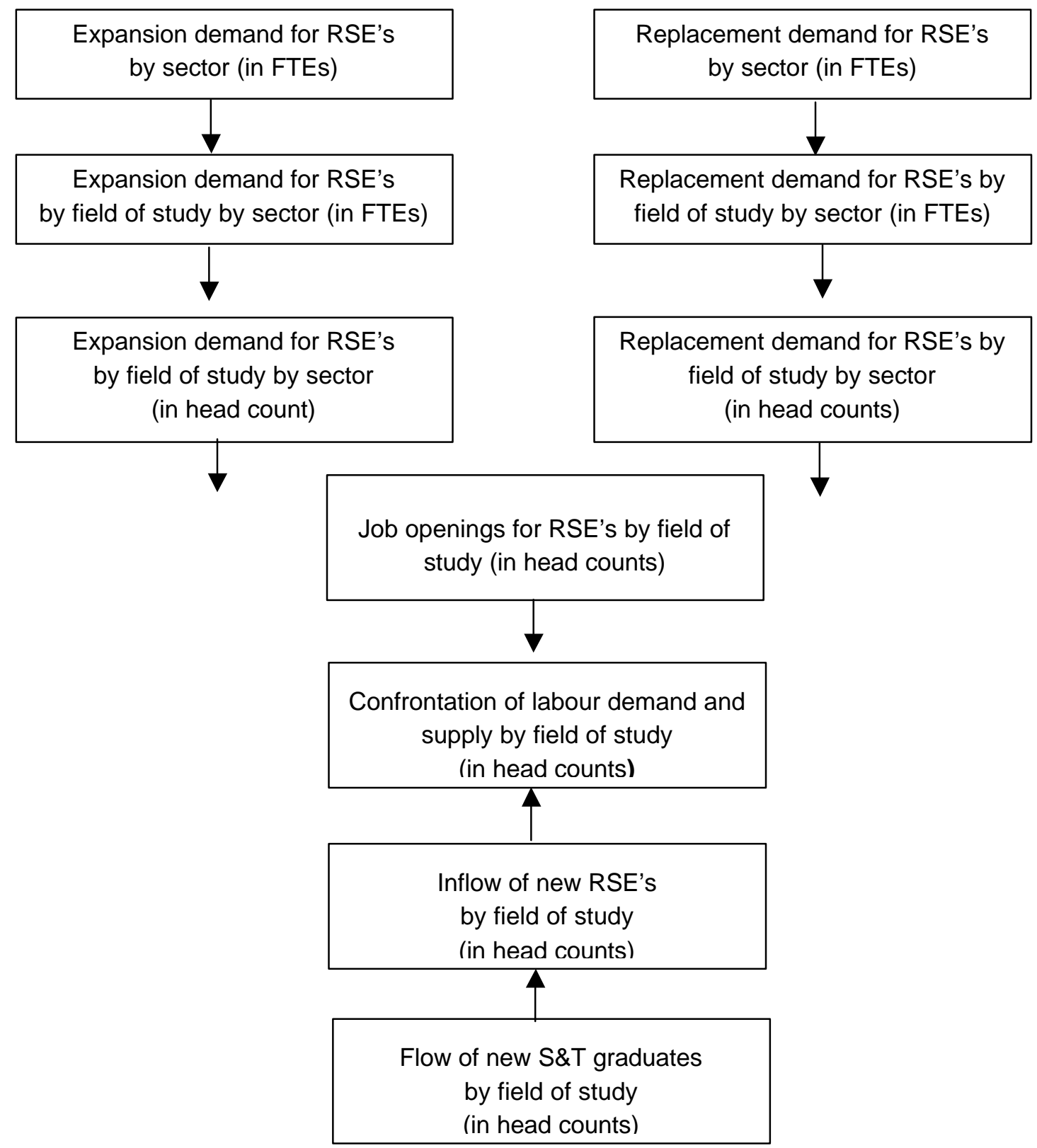

Source: ROA

A country with a relatively young population will generate a relatively larger supply of graduates than a country with a 'greying' population. However, there may also be differences across Member States of the EU in the fields of study that are chosen by prospective students. In the first place, there may be differences in the relative enrolments of students in the S\&T-related fields of study. In the second place, there may be differences in the enrolments in the various fields of study within the S\&T-related fields. In practice only a modest fraction of new S\&T graduates has the qualifications and ambitions to pursue a career as an RSE. Therefore it is important for the confrontation between demand and 
supply to distinguish between the flow of new S\&T graduates and the considerably smaller labour market inflow of new RSE's.

Table 1

Main data sources and crucial assumptions for the model components.

$\begin{array}{lll}\text { Model component } \quad \text { Data source } & \text { Assumptions }\end{array}$

Expansion demand $\quad$ R\&D statistics (Eurostat)

Cointegration of R\&D expenditure and RSE employment by sector (stable long-run relationship)

Replacement demand IES Survey of R\&D establishments Country-specific age structure Country-specific outflow coefficients by age cohort

Inflow S\&T graduate output data Constant growth rates (IES/Eurostat)

Source: ROA

On the supply side we distinguish between four fields of study: natural sciences, technology \& engineering, medical sciences and agricultural sciences. Consequently, for a confrontation between demand and supply we have to express the sectoral expansion demand and the sectoral replacement demand in terms of these four fields of study. Since the supply side forecasts refer to 'head-counts', we also transfer the demand for RSE's from full-time equivalents (FTEs) to head-counts. As a result, the confrontation between demand and supply takes place for 14 Member States of the European Union for the period 1997-2002 in four fields of study in terms of the number of people. An alternative for these so-called 'headcounts' is to express both labour demand and supply in full-time equivalents (FTEs).

The implementation of this general framework is hampered by the lack of adequate data. As a result, we have had to fill the gaps by assumptions and approximations. It is therefore important to distinguish which parts of the forecasting model are firmly grounded in statistical data and which parts are based on hypotheses. In fact, each model component contains a blend of statistical data and ad hoc assumptions. This implies that the forecasts generated by the forecasting model should be interpreted with care. Alternative assumptions will lead to alternative forecasting results. Therefore the forecasts are primarily an illustration of the type of information that can be provided by a forecasting system for the European labour markets for RSE's. The empirical foundation of the pilot model is not yet firm enough for reliable policy conclusions.

We will now discuss the implementation of the three model components in turn. First the expansion demand model is described, then the replacement demand model and finally the inflow model. The central data sources and crucial assumptions for the three components of the model are summarised in table 1. 
In order to get the most accurate forecasts of expansion demand, we developed econometric models for each sector of each Member State of the EU. These models use the sectoral expenditure on $R \& D$ to explain sectoral expansion demand. The use of expenditure data instead of GDP (or Gross Fixed Capital Formation) allows us to capture effects that are specific for the R\&D sector as opposed to the economy as a whole. By distinguishing between three sectors (business enterprise sector, government sector and higher education sector), sector-specific effects can be tracked. Finally, the heterogeneity among the different Member States of the EU can be reflected by the use of specific models for each country. As a result, the forecasting results for expansion demand are based on 42 models ( 14 countries $x 3$ sectors). The models all belong to the class of error correction mechanisms, which are appropriate in the case of non-stationary variables. They also have the advantage of distinguishing between short-run and long-run dynamics. For each sector and for each country the following error correction mechanism is estimated:

$\Delta \mathrm{FTE}_{\mathrm{t}}=\alpha \Delta \mathrm{ERD}_{\mathrm{t}}+\Theta\left(\mathrm{FTE}_{\mathrm{t}-1}-\beta \mathrm{ERD}_{\mathrm{t}-1}\right)+\varepsilon_{\mathrm{t}}$

where FTE denotes the sectoral RSE employment in full-time equivalents and ERD denotes the sectoral expenditure on R\&D in 1990 national currency prices.

The long-run dynamics represents co-integration of FTE and ERD, which means that there is a stable long-run relationship between these two variables, expressed in parameter $\beta$. The short-run dynamics consists of direct effects of increases of ERD on FTE (parameter $\alpha$ ) and corrections for the deviations from the long-run relationship between FTE and ERD (parameter $\Theta$ ), the latter short-run component explains the term 'error correction mechanism'. The model was estimated by the two-step estimation procedure proposed by Engle \& Granger (1987). In the first step, FTE is regressed on ERD which yields a superconsistent estimate of $\beta$. In order to deal with breaks in the data, we added dummy-variables to this regression. In the second step, the estimate of $\beta$ is inserted in the error correction mechanism, which therefore reduces to a linear model which can be estimated by OLS. In addition to the t-statistics for statistical significance of the estimates of $\alpha$ and $\Theta$ and the $\mathrm{R}^{2}$ for the goodness-of-fit, we show the Breusch-Godfrey Lagrange-Multiplier (LM) test for first order serial correlation to measure the adequacy of the dynamic specification. (The DurbinWatson statistic is inappropriate in the presence of lagged endogenous variables). For each of the 42 models, we inspected the statistical significance of the parameter estimates, the plausibility of the signs of $\alpha$ (should be positive) and $\Theta$ (should be negative), the presence of serial correlation and the $\mathrm{R}^{2}$ to select either the general error correction model or one of its two nested simplifications $(\alpha=0$ or $\Theta=0)$. The results of the model selection and estimation are shown in tables $1-4$. An empty cell indicates that one of the two simple versions of the general error correction mechanism was selected.

The uniform approach that we have taken by estimating error correction mechanisms of identical functional form for all countries and sectors avoids ad hocery and data mining. However, the regression statistics show that a uniform approach has its drawbacks, since for some sectors in some countries there are poor statistical fits as evidenced by the low $\mathrm{R}^{2}$. In 
certain cases this may be caused by the data themselves, for example because the dummies for breaks may not have filtered out all noise.

Table 2

Expansion demand model by Member State, business enterprise sector

\begin{tabular}{|c|c|c|c|c|c|c|c|}
\hline Country & $\alpha$ & $\Theta$ & $\beta$ & $\mathrm{t}(\alpha)$ & $\mathrm{t}(\Theta)$ & $\mathrm{LM}$ & $\mathrm{R}^{2}$ \\
\hline Belgium & 0.113 & & & 4.40 & & 0.5 & 0.60 \\
\hline Denmark & 0.384 & & & 15.33 & & 0.8 & 0.95 \\
\hline Germany & 1.995 & -0.379 & 2.282 & 4.48 & -2.16 & 2.7 & 0.68 \\
\hline Greece & 0.026 & & & 6.53 & & 0.8 & 0.77 \\
\hline Spain & 0.009 & & & 2.23 & & 7.1 & 0.28 \\
\hline France & 0.447 & -0.538 & 0.476 & 3.10 & -2.24 & 0.8 & 0.57 \\
\hline Ireland & 4.398 & & & 5.12 & & 0.0 & 0.67 \\
\hline Italy & 0.001 & & & 4.00 & & 3.2 & 0.55 \\
\hline Netherlands & 1.906 & -0.470 & 1.353 & 3.32 & -2.13 & 0.1 & 0.52 \\
\hline Austria & 0.327 & -0.275 & 0.353 & 7.19 & -2.15 & 6.1 & 0.83 \\
\hline Portugal & & -1.403 & 0.028 & & -5.18 & 1.6 & 0.67 \\
\hline Finland & 0.215 & & & 3.37 & & 0.3 & 0.47 \\
\hline Sweden & 0.198 & -0.042 & 0.483 & 5.93 & -1.24 & 2.4 & 0.75 \\
\hline U.K. & 10.177 & -0.252 & 9.723 & 1.59 & -1.08 & 1.1 & 0.18 \\
\hline
\end{tabular}

Source: ROA

Table 3

Expansion demand model by Member State, government sector

\begin{tabular}{|c|c|c|c|c|c|c|c|}
\hline Country & $\alpha$ & $\Theta$ & $\beta$ & $\mathrm{t}(\alpha)$ & $\mathrm{t}(\Theta)$ & LM & $\mathrm{R}^{2}$ \\
\hline Belgium & 0.176 & -0.803 & 0.172 & 4.94 & -2.66 & 1.7 & 0.68 \\
\hline Denmark & 0.662 & & & 4.78 & & 2.4 & 0.64 \\
\hline Germany & 3.003 & -0.451 & 2.787 & 3.04 & -1.86 & 3.5 & 0.47 \\
\hline Greece & 0.009 & & & 0.70 & & 0.6 & 0.04 \\
\hline Spain & 0.021 & & & 2.02 & & 0.0 & 0.24 \\
\hline France & 0.385 & -0.370 & 0.545 & 2.00 & -1.67 & 0.8 & 0.31 \\
\hline Ireland & 2.049 & -0.060 & 11.295 & 0.78 & -1.33 & 9.8 & 0.15 \\
\hline Italy & 0.001 & & & 1.30 & & 0.1 & 0.11 \\
\hline Netherlands & 1.370 & -0.094 & 3.399 & 0.85 & -0.61 & 8.8 & 0.07 \\
\hline Austria & 0.230 & -0.192 & 0.325 & 9.27 & -3.82 & 0.2 & 0.89 \\
\hline Portugal & 0.184 & & & 3.35 & & 0.1 & 0.46 \\
\hline Finland & 0.326 & & & 3.22 & & 1.7 & 0.44 \\
\hline Sweden & 0.624 & -0.087 & 1.154 & 4.04 & -1.84 & 2.2 & 0.59 \\
\hline U.K. & 5.898 & -0.784 & 6.438 & 2.01 & -2.72 & 4.2 & 0.46 \\
\hline
\end{tabular}

Source: ROA

In other cases, it might be the case that different functional forms apply for different sectors of different countries. Estimations in terms of natural logarithms in a uniform way, did not yield better results than the current functional form. Another problem might be that the error 
correction mechanism with one explanatory variable is too simple, introducing omitted variable bias.

Table 4

Expansion demand model by Member State, higher education sector

\begin{tabular}{|c|c|c|c|c|c|c|c|}
\hline Country & $\alpha$ & $\Theta$ & $\beta$ & $\mathrm{t}(\alpha)$ & $\mathrm{t}(\Theta)$ & LM & $\mathrm{R}^{2}$ \\
\hline Belgium & 0.309 & -0.693 & 0.244 & 6.02 & -2.90 & 3.6 & 0.79 \\
\hline Denmark & 0.616 & & & 9.62 & & 1.2 & 0.88 \\
\hline Germany & 4.688 & -0.421 & 4.290 & 5.57 & -2.09 & 3.2 & 0.78 \\
\hline Greece & 0.081 & & & 4.79 & & 0.1 & 0.64 \\
\hline Spain & 0.025 & & & 2.30 & & 1.4 & 0.29 \\
\hline France & 0.641 & & & 4.72 & & 0.0 & 0.63 \\
\hline Ireland & 33.744 & -0.278 & 37.846 & 6.71 & -1.79 & 2.8 & 0.79 \\
\hline Italy & 0.001 & & & 0.75 & & 0.1 & 0.04 \\
\hline Netherlands & 3.995 & -0.609 & 3.093 & 5.08 & -1.90 & 1.6 & 0.69 \\
\hline Austria & 0.190 & & & 10.02 & & 0.0 & 0.89 \\
\hline Portugal & 0.084 & & & 6.89 & & 2.5 & 0.78 \\
\hline Finland & 0.937 & -0.065 & 2.161 & 4.45 & -1.98 & 2.6 & 0.62 \\
\hline Sweden & 0.318 & & & 2.59 & & 0.1 & 0.34 \\
\hline U.K. & 10.927 & -0.117 & 15.808 & 4.16 & -2.15 & 0.4 & 0.62 \\
\hline
\end{tabular}

Source: ROA

One extension might be the incorporation of other explanatory variables. Another extension might be the dynamic specification. For example, the LM-statistic for the Austrian businesssector-model points to first order serial correlation. In any case, it should be kept in mind that the length of the time series is close to the minimum as far as the applicability of error correction mechanism modelling is concerned. In this light, the regression results are quite satisfactory. A final remark can be made on the assumption of a stable long-run relationship between R\&D expenditure and RSE employment. Structural breaks may occur in the composition of R\&D expenditure, as factor prices and relative factor inputs evolve over time. In addition, changes in science funding policies may contribute to changing shares of R\&D expenditure.

Replacement demand is the second source of job openings. While expansion demand is closely related to the growth of the R\&D sector, replacement demand is largely a matter of the demographics of the R\&D sector. It depends on the distribution of the RSE's over the various age cohorts and the probability that an RSE from a specific age cohort will leave. We used RSE stock data from the IES Survey of R\&D Establishments to infer the age structure of the RSE stocks of the Member States of the EU. However, for a number of countries there was a low response rate of the survey in certain sectors, therefore we had to pool the data either over sectors or over countries. Since demographics are country-specific to a large extent, we decided to pool over the sectors and thus obtain country-specific age structures that are uniform across sectors. The probability that a person will flow out of the RSE stock depends on several factors. The most obvious departures result from retirement. Therefore a country with a relatively old labour force will usually have higher replacement demand. 
Another source of replacement demand is the mobility of RSE's to non-RSE jobs within or outside the firm. Often people start their career as an RSE, but then move on to commercial, managerial or other jobs. Since data on the outflow of RSE's were not available from existing sources, relevant questions were included in the IES Survey of R\&D Establishments. The survey data allow us to derive the RSE age structure by country and by sector and also the outflow-coefficients for each cohort by country and by sector. However, because of the low response in certain sectors for a number of countries, we impose uniform outflowcoefficients across sectors for each cohort in each country. This implies we have countryspecific outflow-coefficients. Analogously, we do not use the available data on the age structure in the various sectors in a particular country. Instead we use the more reliable aggregate data on the average age structure in each country, i.e. a country-specific age structure.

In order to confront the number of job openings arising from expansion demand and replacement demand with the inflow of RSE's on the supply side, we have to express the sectoral expansion demand and the sectoral replacement demand in terms of these four fields of study. This is achieved by assuming that the current distribution by field of study remains the same. Since the supply side forecasts refer to 'head-counts', we also transfer the demand for RSE's from full-time equivalents (FTEs) to head-counts. We assume that the ratio between head-counts and FTEs remains constant.

From the supply side, the job openings for RSE's will in general be filled by the flow of new $S \& T$ graduates from the European educational systems. The data on S\&T-graduates in the various Member States of the EU contain information on the enrolments in the various fields of study within the S\&T-related fields. We assume that the growth rates of S\&T-graduates in the various fields of study are constant. The fraction of S\&T-graduates who will pursue a career in R\&D can in principle be derived from First Destination data of S\&T-graduates. Unfortunately, the quality of the available First Destination data is very poor. Therefore we use the available data on changes in RSE employment - in combination with the data on S\&T graduates - as a starting point for the derivation of inflow-coefficients.

\section{Scenario analysis}

\section{Scenarios for the RSE labour market}

Forecasting the European labour markets for research scientists and engineers with our model requires forecasts of expenditure on $R \& D$. A straightforward approach would be to use extrapolations of available time series. However, there are serious drawbacks to this approach. Expenditures on R\&D depend both on the general economic situation and on the policies that are implemented with respect to human capital development. In a prosperous economy there will in general be more funds available for R\&D expenditure. Analogously, in a stagnating economy it may be difficult to raise more funds for $R \& D$ expenditure. However, there still remains an important policy choice as in both situations it is possible to follow either a high human capital growth policy or a low human capital growth policy. 
Since both future developments in GDP and human capital policies are uncertain, we follow a scenario approach - instead of extrapolations - to obtain time paths for R\&D expenditure. We developed 4 scenarios which are based on the combination of 2 dimensions (see table 5): an exogenous dimension and a policy dimension. The exogenous dimension refers to the overall developments in the global economy, which can only be influenced to a limited extent by policy-makers in the EU, since these developments have their causes for a large part in international economic developments. The policy dimension reflects the choices that policymakers in the EU face with respect to R\&D - and education policies. In order to separate the exogenous effects from the policy effects, human capital policies will be indicated by the $R \& D$ expenditure in a country relative to GDP. The interaction of the two dimensions can be represented by the following decomposition of $R \& D$ expenditure: ERD $=G D P \times E R D / G D P$.

Table 5

The four scenarios

High human capital growth policy Low human capital growth policy

High GDP growth

Low GDP growth
GDP growth:

OECD-forecast + $0.5 \%$ Growth of ERD/GDP:

Average of last 5 years

$$
\begin{gathered}
\text { GDP growth: } \\
\text { OECD-forecast }-0.5 \% \\
\text { Growth of ERD/GDP: } \\
\text { Average of last } 5 \text { years }
\end{gathered}
$$

GDP growth:

OECD-forecast + $0.5 \%$ Growth of ERD/GDP:

Zero growth

GDP growth:

OECD-forecast - $0.5 \%$

Growth of ERD/GDP:

Zero growth

Source: ROA

The exogenous dimension is reflected by the time path of GDP, while the human capital policy is indicated by the evolution of the ratio of R\&D expenditure to GDP. In other words, we assume that human capital policy is formulated on terms of $R \& D$ expenditure as a percentage of GDP.

If we consider 2 different outcomes for each dimension, we get 4 possible RSE labour market scenarios (see table 5). The combination of an exogenous dimension and a policy dimension offers a consistent way of building scenarios, instead of making ad hoc assumptions on the various components of the model. Moreover, the interaction of the policy dimension and the exogenous dimension, enables us to get an idea of the effects of human capital policies in the EU in case of both high and low growth paths of the world economy. In this way, the scenarios provide a 'policy-rich' analysis of the labour markets for RSE's in the various EU Member States up to 2002. The scenarios developed are translated into different time paths for R\&D expenditure and different labour market inflow- and outflow-coefficients, capturing the dynamics of the labour market. In turn, the model translates these time paths into forecasts of the supply and demand for RSE's to 2002. 
According to the OECD Employment Outlook June 1998 (OECD, 1998a) the average economic growth rate for the EU in the period 1985-1995 was 2.0 per cent. In 1996 it was even lower at 1.7 per cent, but it picked up in 1997 to 2.6 per cent. The OECD projections for 1998 and 1999 were 2.7 per cent at time of publication. However, the turmoil on the international financial markets has led to a revision of the OECD economic growth projections. The OECD Economic Outlook December 1998 (OECD, 1998b) still has the 1998 growth rate at 2.8 per cent, but the 1999 growth rate is reduced to 2.2 per cent, with a slight recovery in 2000 to 2.5 per cent. This volatility of growth expectations shows that it may be prudent to use scenarios with respect to economic growth. Depending on the effects of for example the financial crises in emerging countries around the world, the situation in Japan and the state of the US economy, but also economic developments within the EU, the EU may face different possible growth rates to 2002.

In the forecasting model, sectoral expansion demand is explained by sectoral $R \& D$ expenditure. In case of higher economic growth, more funds will be available for expenditure on R\&D. In the business enterprise sector, sales and profits rise, which in turn enables firms to invest in their knowledge base. Hence business enterprise expenditure on R\&D (BERD) will increase. In the government sector, the higher economic growth increases government tax receipts. If policy on human capital development is formulated in terms of R\&D expenditure as a fixed percentage of GDP, the larger public budget leads to higher government sector expenditure on R\&D (GOVERD). Since a major part of the higher education sector is funded by the public sector, an increase in economic growth will also benefit the higher education sector expenditure on R\&D (HERD). In short, the cross-sector effect of increased (decreased) economic growth is increased (decreased) expansion demand.

If the high expansion demand resulting from high economic growth cannot be met by adequate supply, then efforts will be made to reduce replacement demand: fewer RSE's in the higher age cohorts will flow out of the labour market by early retirement. Firms engaged in R\&D will try to keep their ageing RSE's employed as long as possible. Probably firms will also induce fewer RSE's to switch to non-RSE jobs. Consequently, the outflow-coefficients will be relatively small in case of high economic growth. Thus replacement demand is assumed to partially compensate movements in expansion demand.

High economic growth means that job opportunities for recent S\&T graduates will probably increase both in RSE jobs and in non-RSE jobs. The effect on the inflow-coefficients will depend on the relative employment growth of RSE jobs versus non-RSE jobs. We assume that economic growth increases the job opportunities in the manufacturing sector more than in the research sector, hence increased economic growth will lead to lower inflowcoefficients.

The assumptions on the effects of economic growth on expansion demand, replacement demand and inflow are summarised in table 6 . 
There are two types of public 'human capital' policies that are relevant for our forecasts. In the first place, policies on R\&D expenditure, which primarily affect the demand side of the labour market for RSE's. In the second place, policies on higher education spending, which affect both the demand and the supply side of the labour market for RSE's. Other policies aimed at the development of human capital, such as tax and levy exemptions on work and aid for recruitment and training, fall outside the scope of this study.

Table 6

Assumptions on the effects of GDP growth on model components

\begin{tabular}{lcc} 
Model component & High GDP growth & Low GDP growth \\
\hline Expansion demand & high & low \\
Replacement demand & low & high \\
Inflow & low & high
\end{tabular}

Source: ROA

Spending on R\&D is subject to budgetary pressures: '. . . the fact that there is close interdependence between the macro economic policies of the European Union and the research and technological innovation policy, means that public financing of $R \& D$ cannot escape the constraints of budgetary reform, which characterise the current economic policy in the Member States of the Union.' (European Commission, 1997, p. 311).

Educational expenditure are also under pressure: 'In almost all OECD countries, total education expenditure accounts for between five and eight per cent of GDP. The public portion of this represents between ten and 15 per cent of public spending. This is a substantial proportion of national income by any standard. Under current conditions of tight public constraints, such a large spending item is subject to close scrutiny by governments looking for ways to trim or limit the growth of expenditure . . ' (OECD, 1997, p. 10).

How do budgetary pressures translate into spending on R\&D and education? In the first place, we assume that R\&D expenditure and public expenditure on higher education will go hand in hand, reflecting a coherent human capital policy. In the second place, budgetary pressures may have different consequences for human capital budgets, depending on the emphasis of the policy-makers. Insights from endogenous growth theory (e.g. Romer, 1990) stress the importance of accumulation of knowledge (through R\&D) and human capital (through education) for sustained long-term growth. If these insights are reflected in government policies, expenditure on R\&D and education will be less affected than other parts of the public sector. In an international context, the situation is even more complicated, since certain countries are still trying to catch up: 'Other Members, despite budgetary problems and restrictions, are seeking to increase public expenditure on $R \& D$. These include 
both countries with a 'catching up' policy like Spain, Portugal, Greece and Ireland, and more developed countries that want to increase or keep emphasis on R\&D.' (European Commission, 1997, p. 314).

Therefore we will distinguish between 2 outcomes of the human capital policy dimension.

Table 7

Assumptions on the effects of human capital policy on model components

\begin{tabular}{lcc} 
Model component & High human capital growth & Low human capital growth \\
\hline Expansion demand & high & low \\
Replacement demand & low & high \\
Inflow & high & low
\end{tabular}

Source: ROA

If the public sector allocates more funds to $R \& D$ and education, then there will be an increase in BERD, GOVERD as well as HERD. This will increase expansion demand for RSE's in all three sectors. At the same time, it means that there will be more funds available to keep older RSE's employed, hence replacement demand will be lower in case of high human capital expenditure. The increase in R\&D funds will, ceteris paribus, lead to an increase in the relative wage of RSE's to all S\&T graduates. Hence the inflow of RSE's will increase. In addition, there is also a long-term effect from the increase in education spending, since it will probably further increase the future supply of S\&T graduates. Since this pilot study has a five-year horizon, this effect may be ignored. However, the general structure of the model developed in this study is capable of incorporating such long-term effects, in particular via the inflow-component. In other words, although the short horizon of the study implies that human capital policy is predominantly expressed in terms of R\&Dpolicy, the forecasting system is also equipped to deal with education policy.

The assumptions on the effects of human capital policy on the various model components are compiled in table 7 .

\section{Quantification of scenarios}

\section{Growth rates of real GDP}

The first question to be addressed when we quantify the scenarios, is to assign specific numerical values to 'high growth' and 'low growth' in the various Member States of the European Union. For this purpose we will use the most recent OECD forecasts (OECD, 1998b), as a baseline growth figure. The high and low growth rates were chosen at equal distances above respectively below the OECD projections. A bandwidth of 1.0 per cent (i.e. 
0.5 per cent above and below the OECD projections), yields the high and low growth figures presented in table 8. This bandwidth is in line with e.g. the expected impact of the crisis in emerging Asia on real GDP growth in the EU which is put at -0.4 per cent for 1998 and -0.2 for 1999 in OECD (1998a) and also in line with the adjustment between May 1998 and December 1998 of the OECD projection for real GDP growth for the EU (because of the effects of the international financial turmoil), which was changed from 2.7 per cent to 2.2 per cent, an adjustment of 0.5 per cent.

\section{Growth rates of the ratio of $R \& D$ expenditure to GDP}

The second issue to be addressed in quantifying the scenarios is to assign numerical values to 'high human capital growth policy' and 'low human capital growth policy'. On this point, it is important to make a distinction between R\&D expenditure in the public sector (GOVERD and HERD) and R\&D expenditure in the private sector (BERD), as data on the financing of $R \& D$ expenditure show that GOVERD and HERD are government-financed, while BERD is only for a minor part financed by the government sector.

Table 8

Exogenous dimension: real GDP growth rates per cent

\begin{tabular}{|c|c|c|c|c|c|c|c|c|c|c|}
\hline \multirow[t]{2}{*}{ Country } & \multicolumn{2}{|c|}{1998} & \multicolumn{2}{|c|}{1999} & \multicolumn{2}{|c|}{2000} & \multicolumn{2}{|c|}{2001} & \multicolumn{2}{|c|}{2002} \\
\hline & High & Low & High & Low & High & Low & High & Low & High & Low \\
\hline Belgium & 3.4 & 2.4 & 2.8 & 1.8 & 2.8 & 1.8 & 2.7 & 1.7 & 2.6 & 1.6 \\
\hline Denmark & 2.9 & 1.9 & 2.5 & 1.5 & 2.4 & 1.4 & 2.9 & 1.9 & 3.0 & 2.0 \\
\hline Germany & 3.2 & 2.2 & 2.7 & 1.7 & 3.0 & 2.0 & 3.1 & 2.1 & 3.2 & 2.2 \\
\hline Greece & 3.5 & 2.5 & 3.7 & 2.7 & 3.9 & 2.9 & 3.6 & 2.6 & 3.4 & 2.4 \\
\hline Spain & 4.3 & 3.3 & 3.9 & 2.9 & 3.9 & 2.9 & 3.9 & 2.9 & 4.0 & 3.0 \\
\hline France & 3.6 & 2.6 & 2.9 & 1.9 & 3.1 & 2.1 & 2.9 & 1.9 & 2.8 & 1.8 \\
\hline Ireland & 9.6 & 8.6 & 7.2 & 6.2 & 7.0 & 6.0 & 7.2 & 6.2 & 7.2 & 6.2 \\
\hline Italy & 2.0 & 1.0 & 2.6 & 1.6 & 3.1 & 2.1 & 3.2 & 2.2 & 3.1 & 2.1 \\
\hline Netherlands & 4.3 & 3.3 & 3.2 & 2.2 & 3.0 & 2.0 & 3.3 & 2.3 & 3.3 & 2.3 \\
\hline Austria & 3.6 & 2.6 & 2.9 & 1.9 & 3.1 & 2.1 & 3.1 & 2.1 & 3.0 & 2.0 \\
\hline Portugal & 4.5 & 3.5 & 3.8 & 2.8 & 3.7 & 2.7 & 3.6 & 2.6 & 3.5 & 2.5 \\
\hline Finland & 5.5 & 4.5 & 3.7 & 2.7 & 3.5 & 2.5 & 3.9 & 2.9 & 3.9 & 2.9 \\
\hline Sweden & 3.3 & 2.3 & 2.7 & 1.7 & 2.9 & 1.9 & 3.1 & 2.1 & 3.1 & 2.1 \\
\hline $\begin{array}{l}\text { United } \\
\text { Kingdom }\end{array}$ & 3.2 & 2.2 & 1.3 & 0.3 & 2.0 & 1.0 & 2.7 & 1.7 & 3.0 & 2.0 \\
\hline
\end{tabular}

\section{Source: OECD/ROA}

We will use constant growth rates of the GOVERD/GDP-ratio and the HERD/GDP-ratio during the entire forecasting period to focus straightforward on two different human capital policies: a low human capital growth policy and a high human capital growth policy. The low human capital growth policy freezes these ERD-to-GDP ratios at the last observed level, i.e. a zero growth policy with respect to the share of public sector R\&D expenditure in GDP. The high human capital growth policy focuses on the RSE labour market impact of a knowledgeintensive growth path, by setting the growth rate of the GOVERD/GDP-ratio and the HERD/GDP-ratio at their respective averages of the last five observed years. We have made 
an exception for the HERD/GDP-ratios of Greece and Spain, which we set at a half of the average growth rate of the last five years. At the very high average growth rate of the last few years, these countries would get implausibly high values for the level of HERD/GDP by the year 2002. In other words, we assume that the R\&D 'catching up'-policies of Greece and Spain in the higher education sector will be sustained in the next few years, albeit at a slower rate such that the R\&D expenditure as a percentage of GDP will reach levels comparable to other European countries in 2002.

Table 9

Scenario growth rates of the ratios of government and higher education R\&D expenditure to GDP

Component of public R\&D expenditure
High human capital growth policy Low human capital growth policy

Average growth rate of total

GOVERD in last 5 years

Average growth rate of total

HERD in last 5 years
Zero growth

Zero growth

HERD

Source: ROA

The scenario growth rates of R\&D expenditure (as a percentage of GDP) in the government sector and the higher education sector are summarised in table 9 and described in more detail in table 11 (government sector) and table 12 (higher education sector).

The effect of human capital policy on the growth rate of the ratio of BERD to GDP depends on the relative role of public financing versus private financing of business enterprise sector expenditure on R\&D. In all Member States of the EU, the size of public financing of $R \& D$ expenditures in the business sector is modest. However, it is often part of stimulation measures which entail co-financing of R\&D expenditure by the public and the private sector. Therefore we assume that the amount of public financing of BERD is accompanied by an equal amount of private financing. Consequently, we can distinguish between private financing of BERD which is independent of public financing (which we simply call 'autonomous BERD') and private financing of BERD which takes place in the context of stimulation measures by the public sector. Therefore we can decompose R\&D expenditure in the business enterprise sector in three parts, as indicated in table 11: publicly-financed $B E R D$, privately financed BERD in the context of stimulation measures and autonomous BERD.

Both in case of 'high human capital growth policy' and 'low human capital growth policy' we assume that the growth rate of the ratio of autonomous BERD to GDP remains constant at the average of the last five observed years in the EU Member State, whereas the effect of human capital policy on the business sector works via privately-financed BERD/GDP in the context of stimulation measures and publicly-financed BERD/GDP. 
In case of a low human capital growth policy we assume, as in the case of the public sector (GOVERD/GDP and HERD/GDP), that publicly-financed BERD/GDP is frozen at the current level. Consequently, also privately-financed BERD/GDP which takes place in the context of stimulation measures will be frozen at the current level. As a result, the growth rate of total $R \& D$ expenditure in the business enterprise sector as a percentage of GDP is below the average growth rate in the last five years. As a matter of fact, the growth of this percentage exclusively originates from autonomous $R \& D$ expenditure in the business enterprise sector.

Table 10

Scenario growth rates of the ratio of BERD to GDP

Component of BERD High human capital growth policy $\quad \begin{gathered}\text { Low human capital growth } \\ \text { policy }\end{gathered}$

Publicly-financed BERD

Privately-financed BERD in the context of stimulation measures

Autonomous BERD

Total BERD
Average growth rate of total BERD in last 5 years

Average growth rate of total BERD in last 5 years

Average growth rate of total BERD in last 5 years

Average growth rate of total $B E R D$ in last 5 years
Zero growth

Zero growth

Average growth rate of total BERD in last 5 years

Below the average growth rate of total BERD in last 5 years

Source: ROA

As in the case of the public sector (GOVERD/GDP and HERD/GDP), we assume that a high human capital growth policy leads to a growth rate of publicly-financed BERD/GDP that is identical to the average of the last five years. The same holds for the growth rate of privatelyfinanced BERD/GDP which takes place in the context of stimulation measures. As a result, in this case the growth rate of BERD/GDP (as a whole) is identical to the average of the last five years. We made an exception for the BERD/GDP-ratios of Greece and Spain, which we set at a half of the average growth rate of the last five years. At the current rate, these countries would get implausibly high values for the level of BERD/GDP by the year 2002. A similar assumption was already made for $R \& D$ expenditure as a percentage of GDP in the public sector in Greece and Spain. In future work on this issue, it may be interesting to further investigate the nature of 'catching up' policies, allowing us to formulate scenarios which address this phenomenon more clearly.

An overview of the resulting growth rates for BERD/GDP during the forecasting period in the various EU Member States, both in case of 'high' and 'low' human capital growth policy, is presented in table 13. Two interesting features emerge from table 13. Firstly, countries with business sectors which depend more on public financing of R\&D expenditure show larger differences between high and low BERD/GDP growth rates (e.g. Greece, France and the United Kingdom). Secondly, in case of the 'low' human capital growth policy BERD/GDP growth rates increase over time. This is due to the fact that the share of privately funded 
BERD increases, as the level of publicly financed BERD is being frozen. Therefore, the BERD/GDP growth rate will in the course of years move towards the growth rate of the ratio of autonomous BERD to GDP.

Table 11

Policy dimension: annual growth rates of government sector expenditure on R\&D as percentages of GDP, 1998-2002

\begin{tabular}{lrr}
\hline Country & & \\
& High & Ler cent \\
& & \\
\hline & & \\
Belgium & 0.0 & -7.8 \\
Denmark & 6.7 & 0.0 \\
Germany & 4.6 & 0.0 \\
Greece & 11.4 & 0.0 \\
Spain & 12.6 & 0.0 \\
France & 4.3 & 0.0 \\
Ireland & 1.2 & 0.0 \\
Italy & 0.0 & 0.7 \\
Netherlands & 6.5 & 0.0 \\
Austria & 6.2 & 0.0 \\
Portugal & 13.8 & 0.0 \\
Finland & 8.5 & 0.0 \\
Sweden & 8.1 & 0.0 \\
United Kingdom & 4.3 & 0.0 \\
& & \\
\hline Source: ROA & & \\
\hline
\end{tabular}

Source: ROA

Table 12

Policy dimension: annual growth rates of higher education sector expenditure on R\&D as percentages of GDP, 1998-2002

Country

Per cent

High Low

$\begin{array}{lrl}\text { Belgium } & 5.1 & 0.0 \\ \text { Denmark } & 10.0 & 0.0 \\ \text { Germany } & 4.7 & 0.0 \\ \text { Greece } & 16.8 & 0.0 \\ \text { Spain } & 13.7 & 0.0 \\ \text { France } & 9.1 & 0.0 \\ \text { Ireland } & 9.1 & 0.0 \\ \text { Italy } & 5.6 & 0.0 \\ \text { Netherlands } & 6.0 & 0.0 \\ \text { Austria } & 6.2 & 0.0 \\ \text { Portugal } & 5.3 & 0.0 \\ \text { Finland } & 9.5 & 0.0 \\ \text { Sweden } & 4.3 & 0.0 \\ \text { United Kingdom } & 8.0 & 0.0\end{array}$

Source: ROA 
Table 13

Policy dimension: annual growth rates of business sector expenditure on $R \& D$ as percentages of GDP, 1998-2002

\begin{tabular}{|c|c|c|c|c|c|c|c|c|c|c|}
\hline \multirow[t]{2}{*}{ Country } & \multicolumn{2}{|c|}{1998} & \multicolumn{2}{|c|}{1999} & \multicolumn{2}{|c|}{2000} & \multicolumn{2}{|c|}{2001} & \multicolumn{2}{|c|}{2002} \\
\hline & High & Low & High & Low & High & Low & High & Low & High & Low \\
\hline Belgium & 5.1 & 4.9 & 5.1 & 4.9 & 5.1 & 4.9 & 5.1 & 4.9 & 5.1 & 4.9 \\
\hline Denmark & 10.0 & 7.4 & 10.0 & 7.5 & 10.0 & 7.7 & 10.0 & 7.9 & 10.0 & 8.0 \\
\hline Germany & 4.7 & 4.0 & 4.7 & 4.0 & 4.7 & 4.0 & 4.7 & 4.1 & 4.7 & 4.1 \\
\hline Greece & 16.8 & 9.2 & 16.8 & 9.9 & 16.8 & 10.5 & 16.8 & 11.1 & 16.8 & 11.7 \\
\hline Spain & 13.7 & 10.3 & 13.7 & 10.6 & 13.7 & 10.9 & 13.7 & 11.2 & 13.7 & 11.4 \\
\hline France & 9.1 & 5.3 & 9.1 & 5.5 & 9.1 & 5.7 & 9.1 & 5.9 & 9.1 & 6.1 \\
\hline Ireland & 9.1 & 8.4 & 9.1 & 8.4 & 9.1 & 8.5 & 9.1 & 8.5 & 9.1 & 8.6 \\
\hline Italy & 5.6 & 5.5 & 5.6 & 5.5 & 5.6 & 5.5 & 5.6 & 5.5 & 5.6 & 5.5 \\
\hline Netherlands & 6.0 & 3.9 & 6.0 & 4.0 & 6.0 & 4.1 & 6.0 & 4.1 & 6.0 & 4.2 \\
\hline Austria & 6.2 & 4.7 & 6.2 & 4.8 & 6.2 & 4.9 & 6.2 & 4.9 & 6.2 & 5.0 \\
\hline Portugal & 5.3 & 4.8 & 5.3 & 4.8 & 5.3 & 4.8 & 5.3 & 4.8 & 5.3 & 4.9 \\
\hline Finland & 9.5 & 8.0 & 9.5 & 8.1 & 9.5 & 8.2 & 9.5 & 8.3 & 9.5 & 8.4 \\
\hline Sweden & 4.3 & 3.4 & 4.3 & 3.4 & 4.3 & 3.4 & 4.3 & 3.4 & 4.3 & 3.5 \\
\hline United & 8.0 & 3.9 & 8.0 & 4.0 & 8.0 & 4.2 & 8.0 & 4.3 & 8.0 & 4.5 \\
\hline Kingdom & & & & & & & & & & \\
\hline
\end{tabular}

Source: ROA

Table 14

Effects of scenarios on variables of the model components

Model component Variable affected by scenario Method of calculation

Expansion demand

Replacement demand

Inflow
Sectoral R\&D expenditure

Outflow-coefficients

Inflow-coefficients
Follows directly from scenario growth paths of GDP and ERD/GDP

Calibration on the basis of the effective age of retirement, which is conditional on the scenario growth paths of GDP and ERD/GDP

Maximum of historical inflow, adjusted for scenario growth paths of GDP and ERD/GDP 


\section{Implementation of scenarios}

\section{Model components}

In section 3, we formulated four scenarios for the labour markets for RSE's in the Member States of the EU. The scenarios were quantified in section 4, by assigning specific values for the growth rates of real GDP (the exogenous dimension) and the growth rates of the ratio of sectoral R\&D expenditure to real GDP (the policy dimension). In this section, the impact of high and low GDP growth and high and low human capital growth policy is translated in terms of the three modules of the forecasting model: expansion demand, replacement demand and labour market inflow of new RSE's. The scenarios affect expansion demand in a straightforward manner, as the expansion demand model explains sectoral RSE employment as a function of sectoral $R \& D$ expenditures. The impact of the scenarios on replacement demand takes place in terms of the outflow-coefficients. The scenarios influence the RSE labour market inflow via the inflow-coefficients. The effects of the scenarios on the three components of the model are summarised in table 14.

\section{Expansion demand}

The growth rate of sectoral expenditure on $R \& D$ can be decomposed into the exogenous GDP growth factor and the human capital policy factor, i.e. the ratio of sectoral expenditure on R\&D to GDP. For example, denote the growth rate of GDP by $g$ and the growth rate of the ERD/GDP-ratio by h. Since

$\mathrm{ERD}_{\mathrm{t}}=\mathrm{GDP}_{\mathrm{t}} \times(\mathrm{ERD} / \mathrm{GDP})_{\mathrm{t}}$

it follows that

$\mathrm{ERD}_{\mathrm{t}} / \mathrm{ERD}_{\mathrm{t}-1}=\mathrm{GDP}_{\mathrm{t}} / \mathrm{GDP}_{\mathrm{t}-1} \times(\mathrm{ERD} / \mathrm{GDP})_{\mathrm{t}} /(\mathrm{ERD} / \mathrm{GDP})_{\mathrm{t}-1}$

Hence the growth rate of ERD, say $f$, is given by

$$
1+f=(1+g)(1+h)
$$

In other words, the growth rate of sectoral expenditure on R\&D can be decomposed into the exogenous GDP growth factor and the human capital policy factor, the ratio of sectoral expenditure on R\&D to GDP. The decomposition shows how the possible outcomes of the two scenario dimensions affect the growth rates of sectoral expenditure on R\&D. Notice that the effect of the growth of GDP on RSE employment is only indirect: it is the combination of GDP growth and human capital policy which determines the growth of R\&D expenditure. Human capital policy is defined as R\&D expenditure as a percentage of GDP, which is a matter of definition, it is not a causal relationship. Although it is possible to consider scenarios where the exogenous dimension plays no role and R\&D expenditure is completely unrelated to the economic situation of the country, it is more plausible to assume that in a prosperous economy there will be more funds available for R\&D expenditure. Analogously, 
in a stagnating economy it may be difficult to raise more funds for R\&D expenditure. Therefore we use the decomposition of the two scenario dimensions to study the interaction of the human capital policy ( $R \& D$ expenditure relative to the economic situation) and the exogenous dimension (the economic situation). The advantage of this approach is that $R \& D$ expenditure is placed in the context of the economic prosperity of each Member State.

The expansion demand-forecasting model directly translates these growth rates of $R \& D$ expenditure into forecasts of RSE employment. From these forecasts we can infer the expansion demand for RSE's in each of the three sectors in the 14 Member States. The growth rates of sectoral R\&D expenditure under the four scenarios follow from table 8 and tables 11-13 via the decomposition.

\section{Replacement demand}

The four scenario paths for sectoral R\&D expenditure affect replacement demand via the outflow-coefficients. Time series data on outflow-coefficients for RSE's in the 14 Member States are not available. The available data, the IES Survey of R\&D Establishments, refer to a single moment in time. This means that we do not have insight into the time series variation of the outflow-coefficients. In order to capture the order of magnitude of the temporal variation of outflow-coefficients, we use the effective age of retirement. Even without scenarios (i.e. in case of extrapolation of current trends), we already would have to use the oldest cohort of RSE's to correct for the under-reporting of outflow in the IES Survey, based on the effective age of retirement. In addition, the oldest cohort of RSE's provides an easily interpretable measure of high and low outflow. We will assume that high outflow corresponds with an effective retirement age of 62 years, while low outflow will be associated with an effective retirement age of 65 years. This gives a straightforward interpretation for the low GDP growth - low human capital growth - scenario (high outflow = 62 years) and for the high GDP growth - high human capital growth - scenario (low outflow $=65$ years). A natural interpretation of the two other scenarios can then be based on the sectoral R\&D expenditure. The effective retirement age for the high GDP growth - low human capital growth - scenario is:

62 years $+\frac{\left(1+g_{H}\right)\left(1+h_{L}\right)-\left(1+g_{L}\right)\left(1+h_{L}\right)}{\left(1+g_{H}\right)\left(1+h_{H}\right)-\left(1+g_{L}\right)\left(1+h_{L}\right)} 3$ years

where $g_{H}\left(g_{L}\right)$ denotes the high (low) GDP growth rate and $h_{H}\left(h_{L}\right)$ denotes the high (low) growth rate of the ratio of sectoral R\&D expenditure to GDP. We use the average growth rates of GDP and R\&D expenditure, since the replacement demand model is (due to data limitations) based on replacement in a period of five years. Analogously, the effective retirement age for the low GDP growth - high human capital growth policy scenario is:

62 years $+\frac{\left(1+g_{L}\right)\left(1+h_{H}\right)-\left(1+g_{L}\right)\left(1+h_{L}\right)}{\left(1+g_{H}\right)\left(1+h_{H}\right)-\left(1+g_{L}\right)\left(1+h_{L}\right)} 3$ years 
Notice that similar formulas for the high-high and the low-low scenarios yield 65 years and 62 years respectively. From the effective retirement age we calculate the scenario-outflowcoefficients for the oldest age cohort. The multiplication factor which is needed to scale up the original survey-outflow-coefficient of the oldest age cohort to the scenario-outflowcoefficient of the oldest age cohort, is then used to scale up the survey-outflow-coefficients of the other age cohorts. Notice that the multiplication factor reflects both the correction for the under-reporting of outflow and the impact of the scenario.

It is obvious that the availability of data on the R\&D labour force should improve. The IES Survey of R\&D Establishments is a step in the right direction, but such surveys should be held at a regular basis. There also remain issues of low response and under-reporting. In this pilot study, we dealt with the low response by making plausible assumptions on the country-specificity of the age structure. In addition, we have tried to correct for underreporting by easily interpretable assumptions on the effective age of retirement, which at the same time can be used to translate the scenarios into outflow-coefficients.

The type of assumptions that were made to deal with the low response and under-reporting, make it difficult to give reliability estimates of the outflow-coefficients and age structure that are used in the scenario forecasts. As a matter of fact, even the confidence intervals of the survey estimates are impossible to obtain. The analysis in Annex 1 of Pearson et al. (2001) nevertheless indicates that the overall sample is fairly representative of the $R \& D$ establishments in each country and overall representative at the sectoral level. However, the survey estimates for Italy are suspect as the low response rate seemed to have worked against the stratification procedure.

\section{Inflow}

Due to the poor quality of the available First Destination Data of S\&T graduates in the European Union, we have to base the inflow-coefficients on RSE employment data. The inflow-coefficients are derived in two steps.

The first step we take in the inflow-analysis is to derive the maximum inflow coefficient based on past observations. New RSE's flow into job openings arise either from expansion demand or from replacement demand. The flow into expansion demand related 'new jobs' can be observed from relative changes in RSE employment (head counts, by field of study). Since the observation period can be compared best with the low GDP growth - high human capital growth - scenario, we can use forecasts of the demand side under this scenario to get an idea of the relative size of expansion demand and replacement demand during the observation period. The results indicate that replacement demand is about a third of all job openings. Hence the maximum inflow coefficient during the observation period can roughly be approximated as 11/atimes the maximum expansion demand inflow coefficient.

The second step is to relate the inflow-coefficients for the different scenarios in the forecasting period to the maximum inflow-coefficient of the observation period. The lack of data on (relative) wages makes it difficult to estimate the relative magnitude of the inflow- 
coefficients in the four scenarios. As an approximation we assume that the inflow-coefficient in period t evolves according to:

$I_{t}=\left(1+h_{t}-g_{t}\right) I_{t-1} \quad t=1998, \ldots, 2002$

where $\mathrm{I}_{1997}$ is the maximum inflow-coefficient of the observation period and $h_{t}$ and $g_{t}$ are the growth rates of real ERD/GDP and real GDP under the specific scenario. Notice that the observations are the net results of demand and supply interactions, hence we use the maximum inflow coefficients of the observation period to approximate the potential RSE inflow.

Figure 2

Summary of the forecasting system with its main assumptions

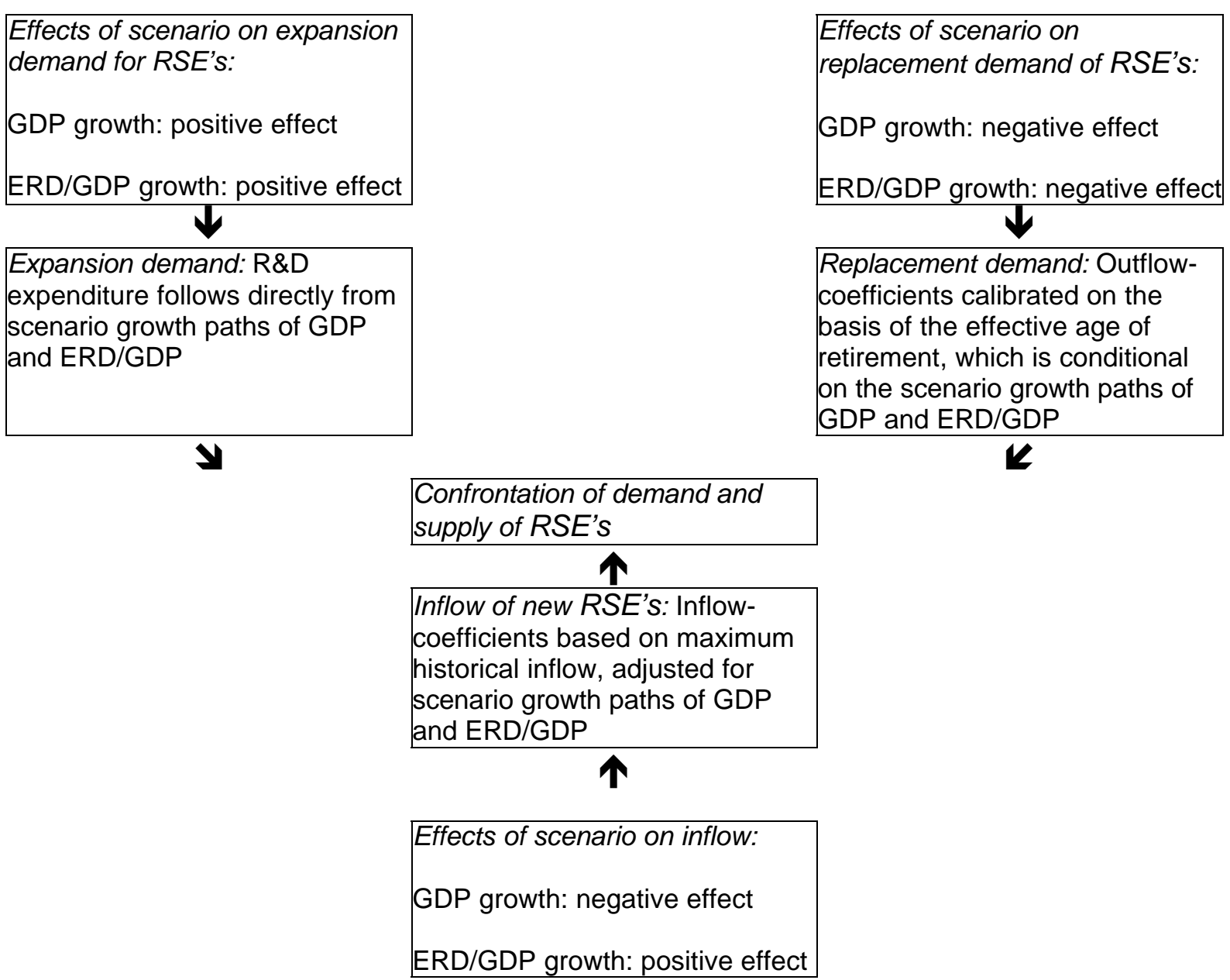

Source: ROA

Obviously, the availability and quality of First Destination Data on S\&T graduates is a problem for modelling the inflow of RSE's. In this pilot study, we have made some strong assumptions in order to compensate for the lack of reliable data. As a matter of fact, it can be argued that the assumptions themselves require empirical study. However, the 
appropriate way to deal with these problems is to improve the collection of data on this crucial segment of the labour market.

Figure 2 provides a summary of the forecasting system that has been developed in this pilot study, featuring the main assumptions that have been made to translate scenarios into demand and supply effects.

\section{Forecasts}

The forecasts for the demand and supply side of the labour markets for new RSE's in the Member States of the European Union to 2002 are compiled in tables 16-75. Each table corresponds with the labour market for new RSE's in one of four fields of study in a specific Member State. Each row of the table corresponds with one of the four scenarios. In each row the three key numbers in assessing the quantitative adequacy of the education system of the Member State are given. The first column ('job openings for RSE's') is the number of job openings (head-counts, not full-time equivalents) for RSE's in this field of study between 1997 and 2002. The second column ('inflow of new RSE's') gives the forecasted supply of new RSE's in this field of study. The third column ('flow of new S\&T graduates') displays the number of new S\&T graduates in this field of study.

The difference between the second and the third column can be explained as follows. The types of jobs that a S\&T graduate can apply for can roughly be classified in two categories: RSE-jobs and non-RSE jobs. Not every S\&T graduate has the abilities or ambitions to get an RSE-job. On this point, moreover, there are large differences between the fields of study distinguished. For an assessment of the quantitative adequacy of the education system to produce sufficient numbers of new RSE's, obviously only the fraction of new S\&T graduates that will apply for RSE-jobs is relevant. This can be done by comparing the first column ('job openings for RSE's') and the second column ('inflow of new RSE's'). As a matter of fact, we have indicated forecasted shortages of RSE's by adding asterisks to the second column. However, the third column ('flow of new S\&T graduates') provides additional information on the potential pool of graduates that can be attracted to RSE jobs under different wages and other job characteristics. (If even this pool is smaller than the number of job openings, we have added asterisks to the third column.) Of course, there will always be considerable numbers of 'competitive' non-RSE-jobs for S\&T-graduates outside the R\&D-sector. Therefore it is unrealistic to consider a large increase of the percentage of S\&T graduates that applies for an RSE job as an easy option.

These forecasts should, however, be interpreted as ex-ante forecasts. In practice, labour markets will exhibit adjustment processes which will bring the difference between labour demand and supply down. This does not mean that there will be no ex-post shortages. It also does not mean that ex-ante shortages matter less: adjustment processes often require high costs. Adjustment processes may take place within the labour market for RSE's of a specific field of study, between labour markets for RSE's with different fields of study and 
between labour markets for RSE's in different countries. The main report discusses potential adjustment processes, several are considered again here.

An important adjustment process on the demand side of the labour market for RSE's with a specific field of study is the time spent by RSE's on non-R\&D tasks. The ratio of head-count to full-time-equivalent indicates the scope for a reduction of the time spent on R\&D. Such a reduction would require a reorganisation of $R \& D$ and non-R\&D tasks, such that activities which specifically require for example natural scientists are performed by natural scientists. Workers with other qualifications (lower level of education or other field of study) can be recruited to perform the non-R\&D tasks. This adjustment process is particularly relevant for the higher education sector where a considerable part of the working time is spent on teaching. Another example of this adjustment process can be found in the IT sector, where academically trained IT-graduates focus on tasks which require a thorough academic background in information technology, while workers which have other educational backgrounds perform activities which require less formal training. When the ex-ante shortage is not too large, this adjustment process may reduce the number of job openings in the ex-post situation to match the level of RSE inflow. A closely related adjustment process is an increase in total working hours, by stimulating overtime of qualified RSE's. Other adjustment strategies that employers may follow to reduce shortages include improved management, substituting physical capital for human capital and even reducing R\&Dactivities (see e.g. Borghans, De Grip and Van Smoorenburg, 1998).

Adjustment processes may also take place on the supply side of the labour market for RSE's with a specific field of study. When the ratio of RSE inflow to total flow of S\&T graduates is relatively small, there may be a hidden potential of S\&T graduates who do not yet apply for RSE jobs in the ex-ante situation, but who may decide to do so in the ex-post situation. Motives may be the good employment opportunities as an RSE or changing job preferences induced by for example promotional campaigns. Of course, higher wages may also be used to attract more RSE's. However, one might wonder if the productivity of these workers in RSE jobs is at the same level as the productivity of the S\&T graduates with a higher preference for RSE jobs. An additional pool of S\&T graduates from which new RSE'S may be recruited are the unemployed. Since the supply forecasts refer to the total flow of S\&T graduates from 1997 to 2002, the relevant figure is the number of unemployed S\&T graduates in 1997. However, according to the labour queue theory (Thurow, 1975), a longer duration of unemployment, on average implies a lower quality of the unemployed S\&T graduate. In addition there may be a loss of skills. Hence both supply side adjustments may be accompanied by a loss in quality and productivity.

An additional adjustment process may take place between labour markets for RSE's with different fields of study. An important opportunity is the similarity between certain natural science curricula and technology \& engineering curricula. For example, a shortage of chemistry RSE's (natural scientists) may be alleviated by an excess supply of chemical engineering RSE's (technology \& engineering). From the demand side this would probably entail a reorganisation of the $R \& D$ tasks of natural scientists and on the supply side it implies that graduates are willing to work outside their field of study. 
Another adjustment process that may take place is international labour mobility. A shortage of natural scientists in one Member State may be reduced by an excess supply of natural scientists from another. Of course, this requires a fully integrated European labour market with a geographically mobile labour force. However, in practice there often are various barriers to mobility such as mutual recognition of educational qualifications, geographical distance, differences in language and culture and fiscal differences. On the other hand, within-company mobility may facilitate international mobility. Incentives for international migration are differences in wages and benefits. After the full introduction of the Euro the lack of transparency of the real wage differentials will decrease, which will probably further facilitate international mobility.

In many instances, international labour mobility may be a considerably less costly adjustment mechanism than the intra-national adjustment mechanisms. According to human capital theory (Mincer, 1958, Schultz, 1961, Becker, 1962), it is an adjustment mechanism which is especially suited for young S\&T graduates. Young people have a longer period to write off the costs of moving to another country, while S\&T graduates have a large knowledge potential which can generate a high income path (Hansen, Heinrich and Nielsen, 1992). Also, international mobility within a multinational firm often relates to higher educated staff.

It is however important to recognise that there are costs both for the demand side and the supply side of the labour market associated with all these adjustment processes. If an exante shortage does not materialise as an (equally large) ex-post shortage due to the adjustment processes described above, this does not mean that the manpower problems are overestimated by the ex-ante shortage. The reduction from the ex-ante shortage to the expost shortage has come at a cost, which in some cases can be considerable. So the ex-ante shortage provides a general indication of the problems associated with the lack of balance between labour demand and supply.

The aggregated results for the European Union are described in tables 16-19. These results are simply obtained by adding up the demand and supply in the 14 Member States. This means that we did not build an aggregate model for the European Union as a whole. In each of the four fields of study, the forecasted inflow of new RSE's exceeds the number of job openings for RSE's, no matter which scenario will unfold between 1997 and 2002. In other words, under perfect labour mobility within the European Union, the higher education systems of the Member States produce adequate numbers of S\&T graduates to meet the demand for new RSE's to 2002.

The results for the various Member States are described in tables 20 onwards. We can distinguish between three groups of countries with respect to the capacity of the national education systems to produce adequate numbers of S\&T-graduates to meet the demands for new RSE's.

The first group consists of the countries which are not expected to have any problems up to 2002: Belgium, Greece, Spain, Finland and the United Kingdom. 
The second group, France and Portugal, are expected to face RSE shortages in case of the high GDP growth - high human capital growth - scenario.

France is expected to face shortages of natural science RSE's in case of a high human capital growth policy. However, since the ratio of inflow to job openings is relatively large, 0.96 in case of low GDP growth and 0.88 in case of high GDP growth, adjustments on the demand side of the labour market which reduce the average time spent by natural science RSE's on non-R\&D tasks by four per cent respectively by 12 per cent, would shrink the number of job openings to match the RSE inflow. An increase in total working hours could also be an instrument to reduce personnel shortages. In addition, on the supply side of the labour market for technology \& engineering RSE's a large excess inflow is forecasted, which could also contribute to solving the shortages of natural science RSE's. Hence the ex-ante shortages will probably not materialise in ex-post shortages, due to adjustment processes on the demand and the supply side.

Portugal is expected to face shortages of natural science RSE's in case of a high human capital growth policy. The ratio of inflow to job openings is 0.95 in case of low GDP growth and 0.89 in case of high GDP growth. This means that an average reduction of 5per cent respectively 11 per cent of non-R\&D activities performed by natural science RSE's could bring the number of job openings down to the level of RSE inflow. An increase in overtime is probably also an effective instrument to accomplish a balanced labour market. The excess inflow of technology \& engineering RSE's may also contribute to alleviating the manpower problems with natural science RSE's. So the shortages of natural science RSE's in Portugal should be manageable. Under the high GDP growth - high human capital growth - scenario, Portugal is also expected to experience shortages of medical science RSE's. Given the ratio of inflow to job openings of 0.93 , a seven per cent reduction of time spent by medical science RSE's on non-R\&D tasks, would bring the labour market for new medical science RSE's in (ex-post) equilibrium. Alternatively, increased overtime could play a role in reducing the shortage.

The scenario-results indicate that France and Portugal will not experience any shortages in case of a low human capital growth policy. A policy of zero-growth of public expenditure on R\&D will avoid the emergence of RSE shortages up to 2002 in France and Portugal. Finally, in none of the scenarios, will France or Portugal face RSE shortages in the fields of technology \& engineering and agricultural sciences.

The third group of Member States, Denmark, Germany, Ireland, Italy, the Netherlands, Austria and Sweden, is expected to face shortages under all four scenarios.

Denmark is expected to experience shortages of natural scientists under all scenarios. Even if the public expenditure on R\&D is frozen at the current fraction of GDP, the expected rate of GDP growth will drive up the absolute level of R\&D expenditure at a rate that causes demand for natural scientists to rise too fast for the inflow of new RSE's from the education system to keep up. As a matter of fact, the number of job openings is even larger than the total flow of new S\&T graduates, so job choice adjustments in favour of the RSE jobs will not 
be able to meet the excess demand. There is also only limited room for adjustment on the demand side, on average a mere seven per cent of the working hours of natural science RSE's are spent on non-R\&D tasks. At the same time, considerable excess supplies of new RSE's in the field of technology \& engineering are forecasted for Denmark. The Danish forecasts for the high GDP growth - high human capital growth scenario yield the largest shortage for natural science RSE's: 3,800. However, the excess supply of technology \& engineering RSE's under this scenario is 9,900 . Consequently if about 40 per cent of this excess inflow can be recruited to meet the demands for natural scientists, then the shortage of natural scientists would be eliminated. Probably, this entails a reorganisation of tasks between natural science RSE's with an educational background in natural sciences and natural science RSE's with a technology \& engineering background. However, using more than a third of the excess supply of technology \& engineering RSE's to fill natural science RSE jobs would also probably be very difficult. So for Denmark, the ex-ante shortages of natural science RSE's are expected to materialise in problematic ex-post shortages under all scenarios. An inflow of natural science RSE's from abroad may be a solution to this problem. International labour mobility will be discussed separately after we have discussed the forecasts for the individual Member States.

Germany is expected to face a shortage of natural science RSE's under all scenarios. Even if natural science RSE's would perform R\&D-activities full-time, which is very unlikely, the number of job openings would still exceed the RSE inflow. Even under the high GDP growth - low human capital growth - scenario, which is expected to yield the smallest discrepancy, such a reduction of non-R\&D tasks would bring down the job openings to 121,400, which leaves a shortage of 9,900 . At the same time under this scenario, there is an excess supply of 30,500 technology \& science RSE's forecasted for Germany, which could also contribute to alleviating the manpower problems for natural science RSE's, although a full elimination of the shortage of natural science RSE's seems unlikely. In the two scenarios with a high human capital growth policy, the problems are even more severe. The number of job openings for natural science RSE's even exceeds the total flow of new S\&T graduates. At the same time the excess supply of new technology \& engineering RSE's is smaller and offers therefore fewer opportunities for substitution. In these two scenarios there is also expected to be a shortage of medical science RSE's. However, the ratio of inflow to job openings for medical science RSE's is rather high. In the high GDP growth - high human capital - scenario this ratio is 0.92 , which means an eight per cent reduction of non-R\&D activities would suffice to eliminate the ex-ante shortage. An increase in overtime may also contribute to reduce the ex-ante shortage. So for Germany the main problems are expected for natural sciences, while the shortages for medical science RSE's under the high human capital scenarios should be manageable. In order to avoid a rationing of $R \& D$ activities in Germany, an inflow of foreign natural science RSE's seems necessary.

The forecasts for Ireland indicate shortages of medical science RSE's. Under the two low human capital growth scenarios, the ratio of inflow to job openings are 0.74 in case of high GDP growth and 0.78 in case of low GDP growth. This means that an average reduction of 26 per cent respectively 22 per cent of non-R\&D tasks by medical science RSE's would reduce the job openings enough to match inflow. Given the relatively high average head- 
counts to FTE ratio, there is room for a considerable reduction of hours spent on non-R\&D tasks. In addition, an increase in total working hours may help to reduce the ex-ante shortage. A complete solution of ex-ante shortages may however not be feasible. Under the high human capital growth scenarios, the required adjustment processes on the demand side are not feasible, since it would require a full elimination of all non-R\&D tasks of medical science RSE's. However, as far as shortages occur in biomedical R\&D, the excess supply of technology \& engineering RSE's could contribute to reduce the shortages of medical RSE's. To summarise, Ireland is expected to face shortages of medical science RSE's which are especially severe under the high human capital growth scenarios. It is therefore very likely that $R \& D$ activities will have to be rationed, unless an inflow of foreign medical science RSE's can take place. This issue will be discussed later.

Italy is also expected to experience shortages of medical science RSE's under all scenarios. The ratio of inflow to job openings is rather high and varies between 0.85 and 0.93 depending on the prevailing scenario. This means that reductions between seven per cent and 15 per cent of non-R\&D activities by medical science RSE's would bring the labour market in equilibrium. Increasing overtime may also help to avoid shortages. Therefore the expected shortages of medical science RSE's in Italy do not seem severe.

The forecasts for the Netherlands indicate RSE shortages for both natural sciences and medical sciences under all four scenarios. The recruitment problems for natural sciences are expected to be most serious, because the number of job openings even by far exceed the total number of S\&T graduates. The ratio of inflow to job openings varies between 0.31 and 0.40 , depending on the scenario. This means that a reduction of hours spent by natural science RSE's on non-R\&D tasks will not be an effective instrument to achieve labour market equilibrium. The excess supplies of technology \& engineering RSE's can also only make a modest contribution to alleviating the recruitment problems for natural science RSE's. The recruitment problems for medical science RSE's are less extreme, but considerable ex-post shortages are still likely. Under the low GDP growth - low human capital growth - scenario it would require a 38 per cent reduction of R\&D-tasks performed by medical science RSE's to bring down the number of job openings to the level of inflow. Under the other three scenarios the ratio of inflow to job openings is too low for this adjustment process - even in theory - to equilibrate the labour market. So any feasible reduction of hours spent on non-R\&D tasks will only contribute modestly to the expected recruitment problems for medical science RSE's in the Netherlands. Increasing overtime will also make no more than a modest contribution to reduce the shortage. The ratio of inflow into RSE jobs to the total supply of new S\&T graduates in medical sciences which in the Netherlands varies between 0.15 and 0.18 , suggests that it may be possible to attract more medical science graduates who in the ex-ante situation do not apply for RSE jobs, but it will not eliminate the shortages. In addition the excess supply of technology \& engineering graduates may contribute to reducing the recruitment problems as far as the shortages for medical science RSE's occur in biomedical research. So in the Netherlands, shortages of natural science RSE's and medical science RSE's are expected. Unless there is an inflow of natural science and medical science RSE's from abroad, a rationing of R\&D-activities in the Netherlands seems unavoidable. 
Austria is expected to have RSE shortages in the fields of natural sciences and medical sciences under all scenarios. The largest problem with natural science RSE's occurs under the high GDP growth - high human capital growth - scenario. The ratio of the inflow of new RSE's $(8,100)$ to the job openings for RSE's $(9,300)$ is 0.87 , which means that a 13 per cent reduction of the time spent on non-R\&D-activities by natural science RSE's would reduce labour demand enough to eliminate the shortages. In addition, there is an excess supply of technology \& engineering RSE's, which could also be recruited to solve the shortages of natural science RSE's. So the manpower problems for natural science RSE's should be manageable. The shortages for medical science RSE's are expected to be more serious, even in case of the smallest discrepancy, which occurs under the low GDP growth - low human capital growth - scenario. The number of job openings could at most be reduced from 5,700 to 3,800 if all medical science RSE's would perform R\&D activities full-time, which is still too much to be filled by the inflow of 2,100 new RSE's. Increasing overtime will also be of limited effect in reducing the shortage. Since the ratio of RSE inflow to the total flow of S\&T graduates is already high, adjustments on the supply side do not offer much help either. So Austria is expected to face serious shortages of medical science RSE's which cannot be solved without an inflow of medical science RSE's from abroad.

For Sweden shortages are expected in all fields of study under all scenarios. However, in Sweden there is considerable room for adjustment both on the demand and the supply side to solve the expected recruitment problems. For natural sciences, technology \& engineering and medical sciences the ratios of inflow to job openings are relatively large. For example, under the high GDP growth - low human capital growth scenario, these ratios are 0.92, 0.95 and 0.81 respectively. This means a reduction of five per cent to 19 per cent of non-R\&D activities by natural science RSE's, technology \& engineering RSE's and medical science RSE's respectively would bring down the numbers of job openings to match the inflow of RSE's. An increase in overtime may also be an effective instrument to solve the recruitment problems. For agricultural sciences adjustments on the demand side will not suffice since the ratio of inflow to job openings is low, for example 0.22 under the high GDP growth - low human capital growth - scenario. The supply side offers considerably more opportunities as the ratio of the RSE jobs inflow to the total number of new S\&T graduates is low $(0.19)$ under that same scenario. This means that it might be possible to divert more S\&T graduates to RSE jobs if competitive job offers are made. Under the high GDP growth - low human capital growth - scenario, it would be sufficient if 4,300 of the 62,200 S\&T graduates who do not apply for RSE jobs in the ex-ante situation - this is only seven per cent - would apply for RSE jobs in the ex-post situation.

The forecasts can be summarised as follows (see also table 15, columns 2-3). There are no shortages of RSE's expected for Belgium, Finland, Greece, Spain and the United Kingdom. France and Portugal may face some shortages under a high human capital growth policy, but these problems are mild and should be manageable by adjustment processes on the demand and supply side. Italy is expected to experience manageable shortages of medical science RSE's under all scenarios. For Sweden shortages are expected in all fields in all scenarios, but they could be solved by adjustments on the demand side (natural sciences, technology \& engineering, medical sciences) and the supply side (agricultural sciences). 
Ireland is expected to face serious shortages of medical science RSE's, especially under high human capital growth scenarios. For Austria, shortages of medical science RSE's are expected, while shortages of natural science RSE's are less severe due to adequate adjustment opportunities. The forecasts for Germany indicate serious shortages of natural science RSE's. Moreover, under the two high human capital growth scenarios, mild shortages of medical science RSE's are expected but these problems should be manageable. Denmark is expected to have serious shortages of natural science RSE's under all scenarios. For the Netherlands, considerable shortages of natural science RSE's and - to a lesser extent - medical science RSE's are expected.

In the discussion of the forecasts so far, we have focussed on the ability of the labour markets of the Member States to reduce the expected shortages, if any, by adjustment processes on the demand side and the supply side within the national labour market. We have seen that not all countries may be able to deal with the RSE manpower problems themselves, specifically Ireland, Austria, Germany, Denmark and the Netherlands. This means that there are opportunities for international labour mobility, since we already saw that there are no shortages expected for the European Union as a whole. The forecasts therefore emphasise the importance of European labour market integration. The shortages of medical science RSE's in Ireland are relatively small compared with the excess supply of medical science RSE's in the United Kingdom in all scenarios, except the high GDP growth - high human capital growth - scenario. Given the short distance, cultural similarity and absence of language problems between Ireland and the United Kingdom, the mobility of medical science RSE's from the latter country to the first would solve the shortages in Ireland. The shortages of medical science RSE's in Austria and the Netherlands can also be solved by mobility from countries with excess supplies, especially France. The shortage of natural science RSE's in Germany are considerable, but countries like Greece, Spain and Italy have considerable excess supplies of graduates with the required educational backgrounds which could fill the job openings. These countries could also contribute to solving the shortages for natural science RSE's in Denmark and the Netherlands.

Table 15 provides an overview of the expected RSE shortages in the various Member States (second column), the effectiveness of intra-national adjustment processes (third column) and the suggested international RSE flows which could solve the most serious shortages (fourth column).

Of course, international labour mobility is not only important in case of the inability of certain Member States to solve their own RSE manpower problems. It may also be a cheaper alternative to costly intra-national adjustment processes in a Member State facing shortages of RSE's. For example, while Sweden is expected to face mild shortages in all fields of study distinguished, Finland has excess supplies in all fields. Since Sweden and Finland are neighbouring countries and the fact that many Finnish people have a good grasp of the Swedish language, the mobility of Finnish RSE's to Sweden would be an answer to the shortages in Sweden, without the costs associated with intra-national adjustment processes. 


\section{Conclusion}

This pilot study has explored the possibilities of developing a forecasting model for the RSE labour markets in the Member States of the European Union to provide an important tool in the assessment of the quantitative adequacy of the European education systems relative to S\&T employment needs. A forecasting model was developed which tracks the relevant flows entering and leaving the labour market for RSE's the period 1997-2002, based on the available data up to 1997. The main problems in the development of the forecasting model were the availability of relevant data on RSE's and the often poor quality of the data that were available. As a result, the empirical foundation of the model showed gaps. Some of the gaps were filled in by the IES Survey of R\&D Establishments, while other gaps had to be closed on the basis of assumptions and approximations. It is therefore essential for any future modelling of the labour market for RSE's in the European Union, that the availability and quality of data on RSE's is improved.

The problems were particularly evident in the replacement demand component and the inflow component of the model. In order to obtain more reliable replacement demand forecasts, it would be very useful if RSE labour force surveys - such as the IES Survey of $R \& D$ Establishments - were performed on a regular basis. In particular, time series data on the composition of the RSE labour force by age and gender would provide a better insight in the outflows of RSE's. Ideally, we would like to have gross flow data indicating whether outflow is due to retirement, job-to-job mobility within the same country or out of the country. In order to get better forecasts of the labour market inflow of RSE's, it is important that the First Destination Data on S\&T graduates improve. A particularly important item in a First Destination survey would be the question whether the respondent has considered applying for an RSE job. This would give a better estimation of the RSE inflow of S\&T graduates than the number of S\&T graduates who actually got RSE jobs.

The forecasting model was used to generate forecasts of the demand and supply side of the labour markets for RSE's in the Member States of the EU up to 2002, under four scenarios.

It is important to emphasise that these forecasts are not yet suitable for policy purposes. The main purpose is to show the potential features of an early warning system for bottlenecks in the labour markets for RSE's which play a crucial role in the European knowledge economy.

The scenarios were designed to capture both the policy options with respect to human capital development and the uncertainty with respect to economic growth. This interaction of a policy dimension and an exogenous dimension, enables us to get an idea of the effects of human capital policies in the EU in case of both high and low growth paths of the world economy. In this way, the scenarios provide a 'policy-rich' analysis of the labour markets for RSE's in the various EU Member States up to 2002. The combination of an exogenous dimension and a policy dimension also offers a consistent way of building scenarios, instead of making ad hoc assumptions on the various components of the model. 
The forecasting results indicated shortages of RSE's in various Member States of the EU. The forecasts for Ireland indicate serious shortages of medical science RSE's, especially under high human capital growth scenarios. For Austria, shortages of medical science RSE's are expected. The forecasts for Germany indicate serious shortages of natural science RSE's. Denmark is expected to have serious shortages of natural science RSE's under all scenarios. For the Netherlands, considerable shortages of natural science RSE's and - to a lesser extent - medical science RSE's are expected.

The forecasting results show that for the European Union as a whole, the forecasted inflow of new RSE's exceeds the number of job openings for RSE's, in each of the four fields of study distinguished, no matter which scenario will unfold between 1997 and 2002. In other words, under perfect labour mobility within the European Union, the higher education systems of the Member States produce adequate numbers of S\&T graduates to meet the demand for new RSE's to 2002. This implies that as far as the adjustment processes of the national labour markets for RSE's are unable to eliminate the shortages, inflow of RSE's from other Member States of the EU could balance RSE demand and supply in the country which faces a shortage.

In particular, countries in which considerable excess supplies of natural science RSE's are expected are Greece, Spain and Italy, while the forecasts for France indicate a large excess supply of medical science RSE's. Inflow of RSE's from a country with an excess supply to a country with a severe shortage would reduce the discrepancy between demand and supply on the labour markets for RSE's in both countries. International labour mobility facilitates the balance between demand and supply on the labour market for RSE's in each Member State of the EU. In fact, this even holds for countries which could achieve equilibrium on the labour market for RSE's without inflow from other countries. Often international mobility is a less costly alternative to domestic adjustment mechanisms. For example, the mild shortages which are expected for Sweden could be solved by inflow of RSE's from Finland.

For future research it is essential that the availability and quality of data improve, especially the first destination data on S\&T graduates and labour force surveys on R\&D personnel. Important topics that should be studied are the flexibility of the labour markets for $R \& D$ personnel in the European Union and the international mobility of R\&D workers. A possibly interesting data source on S\&T graduates is the survey developed in the CHEERS project within the TSER program of DGXII. The CHEERS data give information on the destination of university graduates in various EU Member States: Germany, Spain, France, Italy, the Netherlands, Austria, Finland, Sweden and the United Kingdom.

Better insight of the flows of R\&D workers between Member States of the European Union, but also flows into and out of the European Union is crucial, both from the perspective of technology policy and from the perspective of educational policies. Therefore it is important to collect data on the flows of R\&D workers between countries within and outside the European Union. 
Table 15

Overview of expected RSE shortages and effectiveness of adjustment processes

\begin{tabular}{|c|c|c|c|}
\hline Country & Projected RSE shortages & $\begin{array}{l}\text { Effectiveness of domestic } \\
\text { adjustment processes }\end{array}$ & $\begin{array}{l}\text { Possible sources of } \\
\text { RSE inflow from other } \\
\text { Member States }\end{array}$ \\
\hline Belgium & None & & \\
\hline Denmark & natural sciences & limited & Greece, Spain, Italy \\
\hline Germany & $\begin{array}{l}\text { natural sciences } \\
\text { medical sciences }\end{array}$ & $\begin{array}{l}\text { limited } \\
\text { sufficient }\end{array}$ & Greece, Spain, Italy \\
\hline Greece & None & & \\
\hline Spain & None & & \\
\hline France & natural sciences & sufficient & \\
\hline Ireland & medical sciences & limited & United Kingdom \\
\hline Italy & medical sciences & sufficient & \\
\hline Netherlands & $\begin{array}{l}\text { natural sciences } \\
\text { medical sciences }\end{array}$ & $\begin{array}{l}\text { limited } \\
\text { limited }\end{array}$ & $\begin{array}{l}\text { Greece, Spain, Italy } \\
\text { France }\end{array}$ \\
\hline Austria & $\begin{array}{l}\text { natural sciences } \\
\text { medical sciences }\end{array}$ & $\begin{array}{l}\text { sufficient } \\
\text { limited }\end{array}$ & France \\
\hline $\begin{array}{l}\text { Portugal } \\
\text { Finland }\end{array}$ & $\begin{array}{l}\text { natural sciences } \\
\text { none }\end{array}$ & sufficient & \\
\hline Sweden & $\begin{array}{c}\text { natural sciences } \\
\text { technology \& engineering } \\
\text { medical sciences } \\
\text { aaricultural sciences }\end{array}$ & $\begin{array}{l}\text { sufficient } \\
\text { sufficient } \\
\text { sufficient } \\
\text { sufficient }\end{array}$ & \\
\hline United Kingdom & $\begin{array}{l}\text { none } \\
\text { non }\end{array}$ & sutficient & \\
\hline
\end{tabular}

Source: ROA

Moreover, a deeper understanding is needed of the interaction of the demand side and the supply side of the labour market, both in the short run when the supply of $R \& D$ workers is relatively inelastic and in the long run when educational choices of students may lead to larger changes in the supply of R\&D workers. For further study of the interaction between demand and supply, it is important to have data on wages of R\&D workers. As a first approximation, establishing which part of R\&D expenditure is allocated to gross wage expenditures is a step in the right direction. Such data are available for the Netherlands and have been used to investigate the dynamics of the Dutch labour market for R\&D workers (Marey and Borghans, 2000). With these data it is possible to distinguish between the demand effects and the supply effects of R\&D expenditure on R\&D activities, both in the short run and in the long run. A large accumulation of human capital is embodied in R\&D workers, which takes many years of education and training. As a consequence, the supply of R\&D workers may be very inelastic in the short run. From a policy perspective it is therefore important to get insight in the reaction of the supply of R\&D workers and their wages to an increase in R\&D expenditure. These elasticities of supply determine the limits to public intervention in the R\&D market. The results for the Netherlands can be summarised as follows. In the short run, the small short-term wage elasticity of supply in the Netherlands is compensated by relatively large wage increases. In the long run, the sensitivity of the supply side improves, hence the same increase in employment is achieved by relatively small wage increases. 
This pilot study explored the possibilities of quantifying the labour markets for research scientists and engineers in the European Union, in particular with the aim of assessing the adequacy of the education systems relative to S\&T employment needs. It revealed the limitations of the currently available data and where new data and improved data are needed. It also suggested topics for further research on the labour market for R\&D workers, which is of crucial importance for the knowledge-based economy of the next century. As such the forecasts are not yet suitable for policy purposes. Their main value is to show the potential features of an early warning system for bottlenecks in the labour markets for RSE's which play a crucial role in the European knowledge economy.

\section{References}

Becker G.S. (1962), Investment in Human Capital: A Theoretical Analysis, in: Journal of Political Economy 70, no. 5, pt. 2, pp. 9-49.

Borghans L., A. de Grip, M. van Smoorenburg (1998), Measuring Skills Shortages, ROA-R-1998/4E, Maastricht.

Commission of the European Communities (1993), Growth, Competitiveness, Employment: The Challenges and Ways Forward to the 21st Century, in: Bulletin of the European Communities, Supplement 6/1993, Office for Official Publications of the European Communities, Luxembourg.

Engle R.F., C.W.J. Granger (1987), Co-integration and Error Correction: Representation, Estimation and Testing, in: Econometrica, Vol. 55, pp. 251-276.

European Commission (1997), Second European Report on S\&T Indicators, Office for Official Publications of the European Communities, Luxembourg.

Hansen J.D., H. Heinrich, J.U.-M. Nielsen (1992), An Economic Analysis of the EC, McGraw-Hill, London.

Marey P., L. Borghans (2000), Wage elasticities of the supply of knowledge workers in the Netherlands, Commissioned research for the Dutch Ministry of Economic Affairs, ROA-R-2000/6E, Maastricht.

Mincer J. (1958), Investment in Human Capital and Personal Income Distribution, in: Journal of Political Economy 66, pp. 281-302.

OECD (1994), The OECD Jobs Study: Evidence and Explanations, Paris.

OECD (1997), Education Policy Analysis 1997, Paris.

OECD (1998a), Employment Outlook June 1998, Paris.

OECD (1998b), Employment Outlook December 1998, Paris.

Pearson, R., N. Jagger, H. Connor, S. Perryman, P. Marey, A. de Grip, F.Cörvers (2001), Assessing the Supply and Demand for Scientists and Technologists in Europe, IES Report 377, The Institute for Employment Studies, Brighton, U.K.

Reich R. (1991), The Work of Nations: Preparing Ourselves for Twenty-First Century Capitalism, New York. 
Romer P.M. (1990), Endogenous Technological Change, in: Journal of Political Economy 98, S71S102.

Schultz T.W. (1961), Investment in Human Capital, in: American Economic Review 51, pp.1-17.

Thurow L.C. (1975), Generating Inequality, MacMillan, New York. 


\section{Appendix}

Detailed tables of forecasts

\section{European Union}

Table 16

Natural sciences

\begin{tabular}{lrrr}
\hline Scenario & $\begin{array}{c}\text { Job openings for } \\
\text { RSE's }\end{array}$ & $\begin{array}{c}\text { Inflow of new } \\
\text { RSE's }\end{array}$ & $\begin{array}{c}\text { Flow of new } \\
\text { S\&T graduates }\end{array}$ \\
\hline $\begin{array}{l}\text { Low GDP growth low human capital } \\
\text { High GDP growth low human capital }\end{array}$ & 461,500 & 776,700 & $1,199,600$ \\
$\begin{array}{l}\text { Low GDP growth high human } \\
\text { capital }\end{array}$ & 608,500 & 752,700 & $1,199,600$ \\
$\begin{array}{l}\text { High GDP growth high human } \\
\text { capital }\end{array}$ & 640,200 & 870,100 & $1,199,600$ \\
\hline
\end{tabular}

Source: ROA

Table 17

Technology \& engineering

Scenario

Job openings for RSE'S

Inflow of new

RSE'S

Flow of new

S\&T graduates

$\begin{array}{llll}\text { Low GDP growth low human capital } & 341,600 & 800,700 & 2,306,700 \\ \text { High GDP growth low human capital } & 356,600 & 776,000 & 2,306,700 \\ \text { Low GDP growth high human } & 449,800 & 915,900 & 2,306,700 \\ \begin{array}{l}\text { capital } \\ \text { High GDP growth high human }\end{array} & 473,100 & 888,500 & 2,306,700 \\ \text { capital } & & & \end{array}$

Source: ROA

Table 18

Medical sciences

Scenario

Job openings for

Inflow of new

Flow of new

RSE'S

RSE'S

S\&T graduates

Low GDP growth low human capital

High GDP growth low human capital

220,700

279,000

$1,782,100$

Low GDP growth high human

229,700

270,400

$1,782,100$

capital

288,800

317,500

$1,782,100$

High GDP growth high human

303,600

307,800

$1,782,100$

capital

Source: ROA 
Table 19

Agricultural sciences

\begin{tabular}{lrrr}
\hline Scenario & $\begin{array}{c}\text { Job openings for } \\
\text { RSE's }\end{array}$ & $\begin{array}{c}\text { Inflow of new } \\
\text { RSE's }\end{array}$ & $\begin{array}{c}\text { Flow of new } \\
\text { S\&T graduates }\end{array}$ \\
\hline Low GDP growth low human capital & 75,000 & 122,300 & 325,700 \\
High GDP growth low human capital & 78,100 & 118,600 & 325,700 \\
Low GDP growth high human capital & 97,300 & 140,400 & 325,700 \\
High GDP growth high human capital & 102,300 & 136,100 & 325,700 \\
\hline
\end{tabular}

Source: ROA

\section{Belgium}

Table 20

Natural sciences

\begin{tabular}{lrrr}
\hline Scenario & $\begin{array}{c}\text { Job openings for } \\
\text { RSE's }\end{array}$ & $\begin{array}{c}\text { Inflow of new } \\
\text { RSE's }\end{array}$ & $\begin{array}{c}\text { Flow of new } \\
\text { S\&T graduates }\end{array}$ \\
\hline Low GDP growth low human capital & 11,900 & 19,900 & 24,500 \\
High GDP growth low human capital & 12,700 & 19,300 & 24,500 \\
Low GDP growth high human capital & 14,000 & 20,800 & 24,500 \\
High GDP growth high human capital & 15,000 & 20,200 & 24,500 \\
\hline
\end{tabular}

Source: ROA

Table 21

Technology \& engineering

\begin{tabular}{lrrr}
\hline Scenario & $\begin{array}{c}\text { Job openings for } \\
\text { RSE's }\end{array}$ & $\begin{array}{c}\text { Inflow of new } \\
\text { RSE's }\end{array}$ & $\begin{array}{c}\text { Flow of new } \\
\text { S\&T graduates }\end{array}$ \\
\hline Low GDP growth low human capital & 9,100 & 29,000 & 75,600 \\
High GDP growth low human capital & 9,800 & 28,100 & 75,600 \\
Low GDP growth high human capital & 10,800 & 30,400 & 75,600 \\
High GDP growth high human capital & 11,500 & 29,400 & 75,600 \\
\hline
\end{tabular}

Source: ROA 
Table 22

Medical sciences

\begin{tabular}{lrrr}
\hline Scenario & $\begin{array}{c}\text { Job openings for } \\
\text { RSE's }\end{array}$ & $\begin{array}{c}\text { Inflow of new } \\
\text { RSE's }\end{array}$ & $\begin{array}{c}\text { Flow of new } \\
\text { S\&T graduates }\end{array}$ \\
\hline Low GDP growth low human capital & 5,000 & 9,300 & 56,100 \\
High GDP growth low human capital & 5,300 & 9,000 & 56,100 \\
Low GDP growth high human capital & 5,900 & 9,800 & 56,100 \\
High GDP growth high human capital & 6,300 & 9,500 & 56,100 \\
\hline
\end{tabular}

Source: ROA

Table 23

Agricultural sciences

Scenario

Job openings for

Inflow of new

RSE'S

RSE'S

Flow of new

S\&T graduates

\begin{tabular}{llll} 
Low GDP growth low human capital & 1,700 & 4,700 & 11,500 \\
High GDP growth low human capital & 1,800 & 4,500 & 11,500 \\
Low GDP growth high human capital & 2,000 & 4,900 & 11,500 \\
High GDP growth high human capital & 2,100 & 4,800 & 11,500 \\
\hline
\end{tabular}

Source: ROA

\section{Denmark}

Table 24

Natural sciences

\begin{tabular}{lcrl}
\hline Scenario & $\begin{array}{c}\text { Job openings for } \\
\text { RSE's }\end{array}$ & $\begin{array}{c}\text { Inflow of new } \\
\text { RSE's }\end{array}$ & $\begin{array}{c}\text { Flow of new } \\
\text { S\&T graduates }\end{array}$ \\
\hline Low GDP growth low human capital & 6,100 & $4,400^{*}$ & $5,000^{*}$ \\
High GDP growth low human capital & 6,300 & $4,300^{*}$ & $5,000^{*}$ \\
Low GDP growth high human capital & 7,700 & $4,400^{*}$ & $5,000^{*}$ \\
High GDP growth high human capital & 8,200 & $4,400^{*}$ & $5,000^{*}$
\end{tabular}

Source: ROA 
Table 25

Technology \& engineering

\begin{tabular}{lrrr}
\hline Scenario & $\begin{array}{c}\text { Job openings for } \\
\text { RSE's }\end{array}$ & $\begin{array}{c}\text { Inflow of new } \\
\text { RSE's }\end{array}$ & $\begin{array}{c}\text { Flow of new } \\
\text { S\&T graduates }\end{array}$ \\
\hline Low GDP growth low human capital & 3,500 & 13,000 & 36,800 \\
High GDP growth low human capital & 3,600 & 12,600 & 36,800 \\
Low GDP growth high human capital & 4,400 & 15,000 & 36,800 \\
High GDP growth high human capital & 4,600 & 14,500 & 36,800 \\
\hline
\end{tabular}

Source: ROA

Table 26

Medical sciences

\begin{tabular}{lrrr}
\hline Scenario & $\begin{array}{c}\text { Job openings for } \\
\text { RSE's }\end{array}$ & $\begin{array}{c}\text { Inflow of new } \\
\text { RSE's }\end{array}$ & $\begin{array}{c}\text { Flow of new } \\
\text { S\&T graduates }\end{array}$ \\
\hline Low GDP growth low human capital & 2,300 & 3,800 & 24,100 \\
High GDP growth low human capital & 2,300 & 3,700 & 24,100 \\
Low GDP growth high human capital & 2,900 & 4,400 & 24,100 \\
High GDP growth high human capital & 3,000 & 4,300 & 24,100 \\
\hline
\end{tabular}

Source: ROA

Table 27

Agricultural sciences

\begin{tabular}{lrrr}
\hline Scenario & $\begin{array}{c}\text { Job openings for } \\
\text { RSE's }\end{array}$ & $\begin{array}{c}\text { Inflow of new } \\
\text { RSE's }\end{array}$ & $\begin{array}{c}\text { Flow of new } \\
\text { S\&T graduates }\end{array}$ \\
\hline Low GDP growth low human capital & 1,500 & 2,000 & 3,500 \\
High GDP growth low human capital & 1,500 & 2,000 & 3,500 \\
Low GDP growth high human capital & 1,900 & 2,300 & 3,500 \\
High GDP growth high human capital & 2,000 & 2,200 & 3,500 \\
\hline
\end{tabular}

Source: ROA 


\section{Germany}

Table 28

Natural sciences

\begin{tabular}{lrrr} 
Scenario & $\begin{array}{c}\text { Job openings for } \\
\text { RSE's }\end{array}$ & $\begin{array}{c}\text { Inflow of new } \\
\text { RSE's }\end{array}$ & $\begin{array}{c}\text { Flow of new } \\
\text { S\&T graduates }\end{array}$ \\
\hline Low GDP growth low human capital & 162,500 & $115,000^{*}$ & 182,200 \\
High GDP growth low human capital & 165,100 & $111,500^{*}$ & 182,200 \\
Low GDP growth high human capital & 190,900 & $122,600^{*}$ & $182,200^{*}$ \\
High GDP growth high human capital & 194,600 & $118,900^{*}$ & $182,200^{*}$
\end{tabular}

Source: ROA

Table 29

Technology \& engineering

\begin{tabular}{lrrr} 
Scenario & $\begin{array}{c}\text { Job openings for } \\
\text { RSE's }\end{array}$ & $\begin{array}{c}\text { Inflow of new } \\
\text { RSE's }\end{array}$ & $\begin{array}{c}\text { Flow of new } \\
\text { S\&T graduates }\end{array}$ \\
\hline Low GDP growth low human capital & 124,700 & 162,100 & 501,000 \\
High GDP growth low human capital & 126,700 & 157,200 & 501,000 \\
Low GDP growth high human capital & 146,500 & 172,800 & 501,000 \\
High GDP growth high human capital & 149,400 & 167,700 & 501,000 \\
\hline
\end{tabular}

Source: ROA

Table 30

Medical sciences

Scenario

Job openings for

Inflow of new

Flow of new

RSE's

RSE's

S\&T graduates

Low GDP growth low human capital

High GDP growth low human capital

68,000

72,300

375,700

Low GDP growth high human capital

69,100

70,100

375,700

High GDP growth high human capital

81,500

$77,000^{\star}$

375,700

Source: ROA 
Table 31

Agricultural sciences

\begin{tabular}{lrrr}
\hline Scenario & $\begin{array}{c}\text { Job openings for } \\
\text { RSE's }\end{array}$ & $\begin{array}{c}\text { Inflow of new } \\
\text { RSE's }\end{array}$ & $\begin{array}{c}\text { Flow of new } \\
\text { S\&T graduates }\end{array}$ \\
\hline Low GDP growth low human capital & 22,700 & 26,000 & 78,400 \\
High GDP growth low human capital & 23,000 & 25,200 & 78,400 \\
Low GDP growth high human capital & 26,600 & 28,000 & 78,400 \\
High GDP growth high human capital & 27,200 & $26,900^{*}$ & 78,400 \\
\hline
\end{tabular}

Source: ROA

\section{Greece}

Table 32

Natural sciences

\begin{tabular}{|c|c|c|c|}
\hline Scenario & $\begin{array}{c}\text { Job openings for } \\
\text { RSE's }\end{array}$ & $\begin{array}{l}\text { Inflow of new } \\
\text { RSE's }\end{array}$ & $\begin{array}{l}\text { Flow of new } \\
\text { S\&T graduates }\end{array}$ \\
\hline
\end{tabular}

\begin{tabular}{lrrr}
\hline & & & \\
Low GDP growth low human capital & 6,000 & 25,500 & 35,800 \\
High GDP growth low human capital & 6,500 & 24,700 & 35,800 \\
Low GDP growth high human capital & 16,700 & 31,700 & 35,800 \\
High GDP growth high human capital & 17,600 & 31,600 & 35,800
\end{tabular}

Source: ROA

Table 33

Technology \& engineering

\begin{tabular}{lrrr}
\hline Scenario & $\begin{array}{c}\text { Job openings for } \\
\text { RSE's }\end{array}$ & $\begin{array}{c}\text { Inflow of new } \\
\text { RSE's }\end{array}$ & $\begin{array}{c}\text { Flow of new } \\
\text { S\&T graduates }\end{array}$ \\
\hline Low GDP growth low human capital & 4,000 & 28,700 & 56,100 \\
High GDP growth low human capital & 4,300 & 27,700 & 56,100 \\
Low GDP growth high human capital & 11,100 & 42,600 & 56,100 \\
High GDP growth high human capital & 11,800 & 41,700 & 56,100 \\
\hline
\end{tabular}

Source: ROA 
Table 34

Medical sciences

\begin{tabular}{lrrr}
\hline Scenario & $\begin{array}{c}\text { Job openings for } \\
\text { RSE's }\end{array}$ & $\begin{array}{c}\text { Inflow of new } \\
\text { RSE's }\end{array}$ & $\begin{array}{c}\text { Flow of new } \\
\text { S\&T graduates }\end{array}$ \\
\hline Low GDP growth low human capital & 4,200 & 9,200 & 67,000 \\
High GDP growth low human capital & 4,500 & 8,900 & 67,000 \\
Low GDP growth high human capital & 11,500 & 13,800 & 67,000 \\
High GDP growth high human capital & 12,200 & 13,300 & 67,000 \\
\hline
\end{tabular}

Source: ROA

Table 35

Agricultural sciences

\begin{tabular}{lrrr}
\hline Scenario & $\begin{array}{c}\text { Job openings for } \\
\text { RSE's }\end{array}$ & $\begin{array}{c}\text { Inflow of new } \\
\text { RSE's }\end{array}$ & $\begin{array}{c}\text { Flow of new } \\
\text { S\&T graduates }\end{array}$ \\
\hline Low GDP growth low human capital & 1,200 & 6,600 & 15,600 \\
High GDP growth low human capital & 1,300 & 6,300 & 15,600 \\
Low GDP growth high human capital & 3,400 & 9,900 & 15,600 \\
High GDP growth high human capital & 3,600 & 9,500 & 15,600 \\
\hline
\end{tabular}

Source: ROA

\section{Spain}

Table 36

Natural sciences

\begin{tabular}{lrrr}
\hline Scenario & $\begin{array}{c}\text { Job openings for } \\
\text { RSE's }\end{array}$ & $\begin{array}{c}\text { Inflow of new } \\
\text { RSE's }\end{array}$ & $\begin{array}{c}\text { Flow of new } \\
\text { S\&T graduates }\end{array}$ \\
\hline Low GDP growth low human capital & 18,700 & 79,700 & 104,000 \\
High GDP growth low human capital & 19,500 & 77,200 & 104,000 \\
Low GDP growth high human capital & 30,200 & 90,500 & 104,000 \\
High GDP growth high human capital & 31,900 & 90,100 & 104,000 \\
\hline
\end{tabular}

Source: ROA 
Table 37

Technology \& engineering

\begin{tabular}{lrrr}
\hline Scenario & $\begin{array}{c}\text { Job openings for } \\
\text { RSE's }\end{array}$ & $\begin{array}{c}\text { Inflow of new } \\
\text { RSE's }\end{array}$ & $\begin{array}{c}\text { Flow of new } \\
\text { S\&T graduates }\end{array}$ \\
\hline Low GDP growth low human capital & 12,500 & 64,500 & 117,000 \\
High GDP growth low human capital & 13,000 & 62,500 & 117,000 \\
Low GDP growth high human capital & 20,200 & 81,800 & 117,000 \\
High GDP growth high human capital & 21,300 & 79,300 & 117,000 \\
\hline
\end{tabular}

Source: ROA

Table 38

Medical sciences

\begin{tabular}{lrrr}
\hline Scenario & $\begin{array}{c}\text { Job openings for } \\
\text { RSE's }\end{array}$ & $\begin{array}{c}\text { Inflow of new } \\
\text { RSE's }\end{array}$ & $\begin{array}{c}\text { Flow of new } \\
\text { S\&T graduates }\end{array}$ \\
\hline Low GDP growth low human capital & 12,900 & 19,000 & 128,500 \\
High GDP growth low human capital & 13,500 & 18,400 & 128,500 \\
Low GDP growth high human capital & 20,900 & 24,000 & 128,500 \\
High GDP growth high human capital & 22,100 & 23,300 & 128,500 \\
\hline
\end{tabular}

Source: ROA

Table 39

Agricultural sciences

\begin{tabular}{lrrr}
\hline Scenario & $\begin{array}{c}\text { Job openings for } \\
\text { RSE's }\end{array}$ & $\begin{array}{c}\text { Inflow of new } \\
\text { RSE's }\end{array}$ & $\begin{array}{c}\text { Flow of new } \\
\text { S\&T graduates }\end{array}$ \\
\hline Low GDP growth low human capital & 3,800 & 5,600 & 12,300 \\
High GDP growth low human capital & 4,000 & 5,400 & 12,300 \\
Low GDP growth high human capital & 6,200 & 7,100 & 12,300 \\
High GDP growth high human capital & 6,500 & 6,900 & 12,300 \\
\hline
\end{tabular}

Source: ROA 


\section{France}

Table 40

Natural sciences

Scenario

Job openings for

Inflow of new

Flow of new RSE's

RSE's

S\&T graduates

\begin{tabular}{llll}
\hline Low GDP growth low human capital & 47,000 & 64,600 & 80,200 \\
High GDP growth low human capital & 51,600 & 62,600 & 80,200 \\
Low GDP growth high human capital & 73,200 & $70,600^{*}$ & 80,200 \\
High GDP growth high human capital & 79,600 & $70,200^{*}$ & 80,200 \\
\hline
\end{tabular}

Source: ROA

Table 41

Technology \& engineering

\begin{tabular}{lrrr}
\hline Scenario & $\begin{array}{c}\text { Job openings for } \\
\text { RSE's }\end{array}$ & $\begin{array}{c}\text { Inflow of new } \\
\text { RSE's }\end{array}$ & $\begin{array}{c}\text { Flow of new } \\
\text { S\&T graduates }\end{array}$ \\
\hline Low GDP growth low human capital & 36,100 & 144,300 & 379,300 \\
High GDP growth low human capital & 39,600 & 139,900 & 379,300 \\
Low GDP growth high human capital & 56,200 & 167,600 & 379,300 \\
High GDP growth high human capital & 61,100 & 162,500 & 379,300
\end{tabular}

Source: ROA

Table 42

Medical sciences

Scenario

Job openings for

Inflow of new

Flow of new

RSE's

RSE'S

S\&T graduates

Low GDP growth low human capital

High GDP growth low human capital

19,700

43,300

262,600

Low GDP growth high human capital

21,600

42,000

262,600

High GDP growth high human capital

30,600

50,300

262,600

Source: ROA 
Table 43

Agricultural sciences

\begin{tabular}{lrrr}
\hline Scenario & $\begin{array}{c}\text { Job openings for } \\
\text { RSE's }\end{array}$ & $\begin{array}{c}\text { Inflow of new } \\
\text { RSE's }\end{array}$ & $\begin{array}{c}\text { Flow of new } \\
\text { S\&T graduates }\end{array}$ \\
\hline Low GDP growth low human capital & 6,600 & 11,800 & 29,200 \\
High GDP growth low human capital & 7,200 & 11,400 & 29,200 \\
Low GDP growth high human capital & 10,200 & 13,700 & 29,200 \\
High GDP growth high human capital & 11,100 & 13,200 & 29,200 \\
\hline
\end{tabular}

Source: ROA

\section{Ireland}

Table 44

Natural sciences

\begin{tabular}{lrrr}
\hline Scenario & $\begin{array}{c}\text { Job openings for } \\
\text { RSE's }\end{array}$ & $\begin{array}{c}\text { Inflow of new } \\
\text { RSE's }\end{array}$ & $\begin{array}{c}\text { Flow of new } \\
\text { S\&T graduates }\end{array}$ \\
\hline Low GDP growth low human capital & 12,200 & 27,100 & 44,100 \\
High GDP growth low human capital & 12,700 & 26,300 & 44,100 \\
Low GDP growth high human capital & 17,500 & 29,200 & 44,100 \\
High GDP growth high human capital & 18,200 & 28,200 & 44,100 \\
\hline
\end{tabular}

Source: ROA

Table 45

Technology \& engineering

\begin{tabular}{lrrr} 
Scenario & $\begin{array}{c}\text { Job openings for } \\
\text { RSE's }\end{array}$ & $\begin{array}{c}\text { Inflow of new } \\
\text { RSE's }\end{array}$ & $\begin{array}{c}\text { Flow of new } \\
\text { S\&T graduates }\end{array}$ \\
\hline Low GDP growth low human capital & 3,700 & 12,000 & 43,200 \\
High GDP growth low human capital & 3,800 & 11,600 & 43,200 \\
Low GDP growth high human capital & 5,200 & 12,900 & 43,200 \\
High GDP growth high human capital & 5,400 & 12,500 & 43,200
\end{tabular}

Source: ROA 
Table 46

Medical sciences

\begin{tabular}{lrrr} 
Scenario & $\begin{array}{c}\text { Job openings for } \\
\text { RSE's }\end{array}$ & $\begin{array}{c}\text { Inflow of new } \\
\text { RSE's }\end{array}$ & $\begin{array}{c}\text { Flow of new } \\
\text { S\&T graduates }\end{array}$ \\
\hline Low GDP growth low human capital & 1,800 & $1,400^{*}$ & 9,500 \\
High GDP growth low human capital & 1,900 & $1,300^{*}$ & 9,500 \\
Low GDP growth high human capital & 2,600 & $1,500^{*}$ & 9,500 \\
High GDP growth high human capital & 2,700 & $1,400^{*}$ & 9,500 \\
\hline
\end{tabular}

Source: ROA

Table 47

Agricultural sciences

\begin{tabular}{lcrr}
\hline Scenario & $\begin{array}{c}\text { Job openings for } \\
\text { RSE's }\end{array}$ & $\begin{array}{c}\text { Inflow of new } \\
\text { RSE's }\end{array}$ & $\begin{array}{c}\text { Flow of new } \\
\text { S\&T graduates }\end{array}$ \\
\hline Low GDP growth low human capital & 500 & 1,800 & 3,500 \\
High GDP growth low human capital & 600 & 1,800 & 3,500 \\
Low GDP growth high human capital & 800 & 2,000 & 3,500 \\
High GDP growth high human capital & 800 & 1,900 & 3,500 \\
\hline
\end{tabular}

Source: ROA

\section{Italy}

Table 48

Natural sciences

\begin{tabular}{lrrr}
\hline Scenario & $\begin{array}{c}\text { Job openings for } \\
\text { RSE's }\end{array}$ & $\begin{array}{c}\text { Inflow of new } \\
\text { RSE's }\end{array}$ & $\begin{array}{c}\text { Flow of new } \\
\text { S\&T graduates }\end{array}$ \\
\hline Low GDP growth low human capital & 22,800 & 79,900 & 133,600 \\
High GDP growth low human capital & 23,400 & 77,500 & 133,600 \\
Low GDP growth high human capital & 23,100 & 83,500 & 133,600 \\
High GDP growth high human capital & 24,300 & 80,900 & 133,600 \\
\hline
\end{tabular}

Source: ROA 
Table 49

Technology \& engineering

\begin{tabular}{lrrr}
\hline Scenario & $\begin{array}{c}\text { Job openings for } \\
\text { RSE's }\end{array}$ & $\begin{array}{c}\text { Inflow of new } \\
\text { RSE's }\end{array}$ & $\begin{array}{c}\text { Flow of new } \\
\text { S\&T graduates }\end{array}$ \\
\hline Low GDP growth low human capital & 11,700 & 76,500 & 247,700 \\
High GDP growth low human capital & 12,000 & 74,200 & 247,700 \\
Low GDP growth high human capital & 11,900 & 79,900 & 247,700 \\
High GDP growth high human capital & 12,500 & 77,500 & 247,700 \\
\hline
\end{tabular}

Source: ROA

Table 50

Medical sciences

\begin{tabular}{lrrr}
\hline Scenario & $\begin{array}{c}\text { Job openings for } \\
\text { RSE's }\end{array}$ & $\begin{array}{c}\text { Inflow of new } \\
\text { RSE's }\end{array}$ & $\begin{array}{r}\text { Flow of new } \\
\text { S\&T graduates }\end{array}$ \\
\hline Low GDP growth low human capital & 19,100 & $17,300^{*}$ & 136,900 \\
High GDP growth low human capital & 19,600 & $16,700^{*}$ & 136,900 \\
Low GDP growth high human capital & 19,400 & $18,000^{*}$ & 136,900 \\
High GDP growth high human capital & 20,400 & $17,500^{*}$ & 136,900 \\
\hline
\end{tabular}

Source: ROA

Table 51

Agricultural sciences

\begin{tabular}{lrrr}
\hline Scenario & $\begin{array}{c}\text { Job openings for } \\
\text { RSE's }\end{array}$ & $\begin{array}{c}\text { Inflow of new } \\
\text { RSE's }\end{array}$ & $\begin{array}{c}\text { Flow of new } \\
\text { S\&T graduates }\end{array}$ \\
\hline Low GDP growth low human capital & 8,000 & 10,900 & 29,100 \\
High GDP growth low human capital & 8,200 & 10,600 & 29,100 \\
Low GDP growth high human capital & 8,100 & 11,400 & 29,100 \\
High GDP growth high human capital & 8,500 & 11,100 & 29,100 \\
\hline
\end{tabular}

Source: ROA 


\section{Netherlands}

Table 52

Natural sciences

Scenario

Job openings for

Inflow of new

Flow of new RSE's

RSE's

S\&T graduates

\begin{tabular}{lrrr}
\hline & & & \\
Low GDP growth low human capital & 25,500 & $10,200^{*}$ & $13,400^{*}$ \\
High GDP growth low human capital & 27,000 & $9,900^{*}$ & $13,400^{*}$ \\
Low GDP growth high human capital & 34,000 & $11,500^{*}$ & $13,400^{*}$ \\
High GDP growth high human capital & 36,400 & $11,200^{*}$ & $13,400^{*}$
\end{tabular}

Source: ROA

Table 53

Technology \& engineering

\begin{tabular}{lrrr} 
Scenario & $\begin{array}{c}\text { Job openings for } \\
\text { RSE's }\end{array}$ & $\begin{array}{c}\text { Inflow of new } \\
\text { RSE's }\end{array}$ & $\begin{array}{c}\text { Flow of new } \\
\text { S\&T graduates }\end{array}$ \\
\hline Low GDP growth low human capital & 19,600 & 29,700 & 82,400 \\
High GDP growth low human capital & 20,800 & 28,800 & 82,400 \\
Low GDP growth high human capital & 26,100 & 33,700 & 82,400 \\
High GDP growth high human capital & 27,900 & 32,700 & 82,400
\end{tabular}

Source: ROA

Table 54

Medical sciences

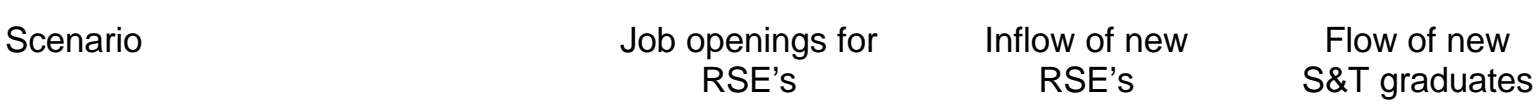

Low GDP growth low human capital

$10,700 \quad 6,600^{*}$

42,300

High GDP growth low human capital

11,300

$6,400^{*}$

42,300

Low GDP growth high human capital

14,200

$7,500^{*}$

42,300

High GDP growth high human capital

15,200

$7,300^{*}$

42,300

Source: ROA 
Table 55

Agricultural sciences

\begin{tabular}{lrrr}
\hline Scenario & $\begin{array}{c}\text { Job openings for } \\
\text { RSE's }\end{array}$ & $\begin{array}{c}\text { Inflow of new } \\
\text { RSE's }\end{array}$ & $\begin{array}{c}\text { Flow of new } \\
\text { S\&T graduates }\end{array}$ \\
\hline Low GDP growth low human capital & 3,600 & 6,300 & 16,500 \\
High GDP growth low human capital & 3,800 & 6,100 & 16,500 \\
Low GDP growth high human capital & 4,700 & 7,100 & 16,500 \\
High GDP growth high human capital & 5,100 & 6,900 & 16,500 \\
\hline
\end{tabular}

Source: ROA

\section{Austria}

Table 56

Natural sciences

\begin{tabular}{lrrr}
\hline Scenario & $\begin{array}{c}\text { Job openings for } \\
\text { RSE's }\end{array}$ & $\begin{array}{c}\text { Inflow of new } \\
\text { RSE's }\end{array}$ & $\begin{array}{c}\text { Flow of new } \\
\text { S\&T graduates }\end{array}$ \\
\hline Low GDP growth low human capital & 7,900 & $7,500^{*}$ & 10,300 \\
High GDP growth low human capital & 8,200 & $7,300^{*}$ & 10,300 \\
Low GDP growth high human capital & 8,800 & $8,300^{*}$ & 10,300 \\
High GDP growth high human capital & 9,300 & $8,100^{*}$ & 10,300 \\
\hline
\end{tabular}

Source: ROA

Table 57

Technology \& engineering

\begin{tabular}{lrrr}
\hline Scenario & $\begin{array}{c}\text { Job openings for } \\
\text { RSE's }\end{array}$ & $\begin{array}{c}\text { Inflow of new } \\
\text { RSE's }\end{array}$ & $\begin{array}{r}\text { Flow of new } \\
\text { S\&T graduates }\end{array}$ \\
\hline Low GDP growth low human capital & 3,900 & 4,900 & 15,800 \\
High GDP growth low human capital & 4,000 & 4,700 & 15,800 \\
Low GDP growth high human capital & 4,300 & 5,400 & 15,800 \\
High GDP growth high human capital & 4,500 & 5,300 & 15,800 \\
\hline
\end{tabular}

Source: ROA 
Table 58

Medical sciences

\begin{tabular}{lrrr} 
Scenario & $\begin{array}{c}\text { Job openings for } \\
\text { RSE's }\end{array}$ & $\begin{array}{c}\text { Inflow of new } \\
\text { RSE's }\end{array}$ & $\begin{array}{c}\text { Flow of new } \\
\text { S\&T graduates }\end{array}$ \\
\hline Low GDP growth low human capital & 5,700 & $2,100^{*}$ & 10,900 \\
High GDP growth low human capital & 5,900 & $2,000^{*}$ & 10,900 \\
Low GDP growth high human capital & 6,400 & $2,300^{*}$ & 10,900 \\
High GDP growth high human capital & 6,700 & $2,300^{*}$ & 10,900 \\
\hline
\end{tabular}

Source: ROA

Table 59

Agricultural sciences

\begin{tabular}{lcrr}
\hline Scenario & $\begin{array}{c}\text { Job openings for } \\
\text { RSE's }\end{array}$ & $\begin{array}{c}\text { Inflow of new } \\
\text { RSE's }\end{array}$ & $\begin{array}{c}\text { Flow of new } \\
\text { S\&T graduates }\end{array}$ \\
\hline Low GDP growth low human capital & 900 & 1,400 & 4,300 \\
High GDP growth low human capital & 1,000 & 1,400 & 4,300 \\
Low GDP growth high human capital & 1,000 & 1,600 & 4,300 \\
High GDP growth high human capital & 1,100 & 1,500 & 4,300 \\
\hline
\end{tabular}

Source: ROA

\section{Portugal}

Table 60

Natural sciences

\begin{tabular}{lrrr}
\hline Scenario & $\begin{array}{c}\text { Job openings for } \\
\text { RSE's }\end{array}$ & $\begin{array}{c}\text { Inflow of new } \\
\text { RSE's }\end{array}$ & $\begin{array}{c}\text { Flow of new } \\
\text { S\&T graduates }\end{array}$ \\
\hline Low GDP growth low human capital & 6,900 & 12,400 & 16,800 \\
High GDP growth low human capital & 7,500 & 12,000 & 16,800 \\
Low GDP growth high human capital & 15,500 & $14,800^{*}$ & 16,800 \\
High GDP growth high human capital & 16,600 & $14,700^{*}$ & 16,800 \\
\hline
\end{tabular}

Source: ROA 
Table 61

Technology \& engineering

\begin{tabular}{lrrr}
\hline Scenario & $\begin{array}{c}\text { Job openings for } \\
\text { RSE's }\end{array}$ & $\begin{array}{c}\text { Inflow of new } \\
\text { RSE's }\end{array}$ & $\begin{array}{c}\text { Flow of new } \\
\text { S\&T graduates }\end{array}$ \\
\hline Low GDP growth low human capital & 5,300 & 17,500 & 50,500 \\
High GDP growth low human capital & 5,800 & 17,000 & 50,500 \\
Low GDP growth high human capital & 11,900 & 22,100 & 50,500 \\
High GDP growth high human capital & 12,700 & 21,400 & 50,500 \\
\hline
\end{tabular}

Source: ROA

Table 62

Medical sciences

\begin{tabular}{lrrr}
\hline Scenario & $\begin{array}{c}\text { Job openings for } \\
\text { RSE's }\end{array}$ & $\begin{array}{c}\text { Inflow of new } \\
\text { RSE's }\end{array}$ & $\begin{array}{c}\text { Flow of new } \\
\text { S\&T graduates }\end{array}$ \\
\hline Low GDP growth low human capital & 2,900 & 5,200 & 34,800 \\
High GDP growth low human capital & 3,100 & 5,100 & 34,800 \\
Low GDP growth high human capital & 6,500 & 6,600 & 34,800 \\
High GDP growth high human capital & 6,900 & $6,400^{*}$ & 34,800 \\
\hline
\end{tabular}

Source: ROA

Table 63

Agricultural sciences

\begin{tabular}{lrrr}
\hline Scenario & $\begin{array}{c}\text { Job openings for } \\
\text { RSE's }\end{array}$ & $\begin{array}{c}\text { Inflow of new } \\
\text { RSE's }\end{array}$ & $\begin{array}{c}\text { Flow of new } \\
\text { S\&T graduates }\end{array}$ \\
\hline Low GDP growth low human capital & 1,000 & 4,900 & 13,500 \\
High GDP growth low human capital & 1,000 & 4,800 & 13,500 \\
Low GDP growth high human capital & 2,200 & 6,200 & 13,500 \\
High GDP growth high human capital & 2,300 & 6,000 & 13,500 \\
\hline
\end{tabular}

Source: ROA 


\section{Finland}

Table 64

Natural sciences

\begin{tabular}{lccc} 
Scenario & $\begin{array}{c}\text { Job openings for } \\
\text { RSE's }\end{array}$ & $\begin{array}{c}\text { Inflow of new } \\
\text { RSE's }\end{array}$ & $\begin{array}{c}\text { Flow of new } \\
\text { S\&T graduates }\end{array}$ \\
\hline Low GDP growth low human capital & 3,700 & 13,100 & 19,800 \\
High GDP growth low human capital & 3,900 & 12,700 & 19,800 \\
Low GDP growth high human capital & 5,100 & 14,800 & 19,800 \\
High GDP growth high human capital & 5,300 & 14,400 & 19,800 \\
\hline
\end{tabular}

Source: ROA

Table 65

Technology \& engineering

\begin{tabular}{lrrr} 
Scenario & $\begin{array}{c}\text { Job openings for } \\
\text { RSE's }\end{array}$ & $\begin{array}{c}\text { Inflow of new } \\
\text { RSE's }\end{array}$ & $\begin{array}{c}\text { Flow of new } \\
\text { S\&T graduates }\end{array}$ \\
\hline Low GDP growth low human capital & 4,000 & 15,100 & 44,600 \\
High GDP growth low human capital & 4,200 & 14,700 & 44,600 \\
Low GDP growth high human capital & 5,400 & 17,100 & 44,600 \\
High GDP growth high human capital & 5,700 & 16,600 & 44,600
\end{tabular}

Source: ROA

Table 66

Medical sciences

$\begin{array}{cccc}\text { Scenario } & \text { Job openings for } & \text { Inflow of new } & \text { Flow of new } \\ \text { RSE's } & \text { RSE's } & \text { S\&T graduates }\end{array}$

Low GDP growth low human capital High GDP growth low human capital Low GDP growth high human capital High GDP growth high human capital

$\begin{array}{lll}4,400 & 14,300 & 70,800 \\ 4,600 & 13,900 & 70,800 \\ 6,000 & 16,100 & 70,800 \\ 6,300 & 15,600 & 70,800\end{array}$

Source: ROA 
Table 67

Agricultural sciences

\begin{tabular}{lrrr}
\hline Scenario & $\begin{array}{c}\text { Job openings for } \\
\text { RSE's }\end{array}$ & $\begin{array}{c}\text { Inflow of new } \\
\text { RSE's }\end{array}$ & $\begin{array}{c}\text { Flow of new } \\
\text { S\&T graduates }\end{array}$ \\
\hline Low GDP growth low human capital & 1,600 & 3,400 & 9,900 \\
High GDP growth low human capital & 1,700 & 3,300 & 9,900 \\
Low GDP growth high human capital & 2,300 & 3,900 & 9,900 \\
High GDP growth high human capital & 2,400 & 3,800 & 9,900 \\
\hline
\end{tabular}

Source: ROA

\section{Sweden}

Table 68

Natural sciences

\begin{tabular}{lrrr}
\hline Scenario & $\begin{array}{c}\text { Job openings for } \\
\text { RSE's }\end{array}$ & $\begin{array}{c}\text { Inflow of new } \\
\text { RSE's }\end{array}$ & $\begin{array}{c}\text { Flow of new } \\
\text { S\&T graduates }\end{array}$ \\
\hline Low GDP growth low human capital & 12,400 & $11,600^{*}$ & 18,400 \\
High GDP growth low human capital & 12,300 & $11,300^{*}$ & 18,400 \\
Low GDP growth high human capital & 13,100 & $12,300^{*}$ & 18,400 \\
High GDP growth high human capital & 13,400 & $11,900^{*}$ & 18,400 \\
\hline
\end{tabular}

Source: ROA

Table 69

Technology \& engineering

\begin{tabular}{lrrr}
\hline Scenario & $\begin{array}{c}\text { Job openings for } \\
\text { RSE's }\end{array}$ & $\begin{array}{c}\text { Inflow of new } \\
\text { RSE's }\end{array}$ & $\begin{array}{r}\text { Flow of new } \\
\text { S\&T graduates }\end{array}$ \\
\hline Low GDP growth low human capital & 13,400 & $12,900^{*}$ & 39,800 \\
High GDP growth low human capital & 13,200 & $12,500^{*}$ & 39,800 \\
Low GDP growth high human capital & 14,100 & $13,600^{*}$ & 39,800 \\
High GDP growth high human capital & 14,400 & $13,200^{*}$ & 39,800 \\
\hline
\end{tabular}

Source: ROA 
Table 70

Medical sciences

\begin{tabular}{lrrr} 
Scenario & $\begin{array}{c}\text { Job openings for } \\
\text { RSE's }\end{array}$ & $\begin{array}{c}\text { Inflow of new } \\
\text { RSE's }\end{array}$ & $\begin{array}{c}\text { Flow of new } \\
\text { S\&T graduates }\end{array}$ \\
\hline Low GDP growth low human capital & 14,700 & $12,200^{*}$ & 63,400 \\
High GDP growth low human capital & 14,600 & $11,800^{*}$ & 63,400 \\
Low GDP growth high human capital & 15,500 & $12,900^{*}$ & 63,400 \\
High GDP growth high human capital & 15,900 & $12,500^{*}$ & 63,400 \\
\hline
\end{tabular}

Source: ROA

Table 71

Agricultural sciences

\begin{tabular}{lrrr}
\hline Scenario & $\begin{array}{c}\text { Job openings for } \\
\text { RSE's }\end{array}$ & $\begin{array}{c}\text { Inflow of new } \\
\text { RSE's }\end{array}$ & $\begin{array}{c}\text { Flow of new } \\
\text { S\&T graduates }\end{array}$ \\
\hline Low GDP growth low human capital & 5,500 & $1,200^{*}$ & 63,400 \\
High GDP growth low human capital & 5,500 & $1,200^{*}$ & 63,400 \\
Low GDP growth high human capital & 5,800 & $1,300^{*}$ & 63,400 \\
High GDP growth high human capital & 6,000 & $1,300^{*}$ & 63,400 \\
\hline
\end{tabular}

Source: ROA

\section{United Kingdom}

Table 72

Natural sciences

\begin{tabular}{lrrr}
\hline Scenario & $\begin{array}{c}\text { Job openings for } \\
\text { RSE's }\end{array}$ & $\begin{array}{c}\text { Inflow of new } \\
\text { RSE's }\end{array}$ & $\begin{array}{c}\text { Flow of new } \\
\text { S\&T graduates }\end{array}$ \\
\hline Low GDP growth low human capital & 117,700 & 305,800 & 511,600 \\
High GDP growth low human capital & 124,800 & 296,200 & 511,600 \\
Low GDP growth high human capital & 158,600 & 355,000 & 511,600 \\
High GDP growth high human capital & 169,700 & 344,100 & 511,600 \\
\hline
\end{tabular}

Source: ROA 
Table 73

Technology \& engineering

\begin{tabular}{lrrr}
\hline Scenario & $\begin{array}{c}\text { Job openings for } \\
\text { RSE's }\end{array}$ & $\begin{array}{c}\text { Inflow of new } \\
\text { RSE's }\end{array}$ & $\begin{array}{c}\text { Flow of new } \\
\text { S\&T graduates }\end{array}$ \\
\hline Low GDP growth low human capital & 90,300 & 190,400 & 617,000 \\
High GDP growth low human capital & 95,800 & 184,400 & 617,000 \\
Low GDP growth high human capital & 121,700 & 221,100 & 617,000 \\
High GDP growth high human capital & 130,200 & 214,300 & 617,000 \\
\hline
\end{tabular}

Source: ROA

Table 74

Medical sciences

\begin{tabular}{lrrr}
\hline Scenario & $\begin{array}{c}\text { Job openings for } \\
\text { RSE's }\end{array}$ & $\begin{array}{c}\text { Inflow of new } \\
\text { RSE's }\end{array}$ & $\begin{array}{r}\text { Flow of new } \\
\text { S\&T graduates }\end{array}$ \\
\hline Low GDP growth low human capital & 49,300 & 63,000 & 499,600 \\
High GDP growth low human capital & 52,300 & 61,000 & 499,600 \\
Low GDP growth high human capital & 66,400 & 73,100 & 499,600 \\
High GDP growth high human capital & 71,000 & $70,900^{*}$ & 499,600 \\
\hline
\end{tabular}

Source: ROA

Table 75

Agricultural sciences

\begin{tabular}{lrrr}
\hline Scenario & $\begin{array}{c}\text { Job openings for } \\
\text { RSE's }\end{array}$ & $\begin{array}{c}\text { Inflow of new } \\
\text { RSE's }\end{array}$ & $\begin{array}{c}\text { Flow of new } \\
\text { S\&T graduates }\end{array}$ \\
\hline Low GDP growth low human capital & 16,400 & 35,600 & 94,800 \\
High GDP growth low human capital & 17,400 & 34,500 & 94,800 \\
Low GDP growth high human capital & 22,100 & 41,400 & 94,800 \\
High GDP growth high human capital & 23,700 & 40,100 & 94,800 \\
\hline
\end{tabular}

Source: ROA 